\title{
Epipalaeolithic and Neolithic gazelle hunting in the Badia of north-east Jordan. Reconstruction of seasonal movements of herds by stable isotope and dental microwear analyses
}

\author{
Elizabeth Henton ${ }^{1}$, Joseph Roe ${ }^{1}$, Louise Martin ${ }^{1}$, Andrew Garrard ${ }^{1}$, Oliver Boles ${ }^{1}$, Jamie \\ Lewis $^{2}$, Matthew Thirlwall ${ }^{3}$, Anne-Lise Jourdon ${ }^{4}$
}

\begin{abstract}
${ }^{1}$ UCL Institute of Archaeology, University College London, UK; ${ }^{2}$ School of Earth Sciences, University of Bristol, UK; ${ }^{3}$ Department of Earth Sciences, Royal Holloway, University of London, UK; ${ }^{4}$ Bloomsbury Environmental Isotope Facility, University College London, UK
\end{abstract}

Elizabeth Henton (corresponding author), UCL Institute of Archaeology, 31-34 Gordon Square, London WC1H OPY, UK: Email: e.henton@ucl.ac.uk

\begin{abstract}
In the north-east Jordan steppe, gazelle were of considerable economic importance to human groups during the Epipalaeolithic and Neolithic. An influential model argues that gazelle herds migrated through the region and were only seasonally available to hunters. This study tests that model, asking whether gazelle were indeed highly seasonally mobile during these time frames, or whether they could have remained more local, adapted to periodically resource-rich habitats, and thus been available to hunters throughout the year. Interpretation of animal location, diet and season, through stable isotope analyses and microwear studies of archaeological gazelle teeth from ten chronologically and spatially varied sites, suggests herds did not migrate. Rather, gazelle appear to have had relatively local year round habitats in the steppe during the Epipalaeolithic at least, while possibly ranging further and becoming more mobile in the Neolithic.
\end{abstract}

Keywords: hunting seasonality, Epipalaeolithic, Neolithic, stable isotopes, dental microwear analysis

\section{$1 \quad$ Introduction}

This paper seeks to make a contribution to the long-standing debate on factors underlying human habitation of the north-east Jordan steppe/desert (Badia) during the Epipalaeolithic and Neolithic (Betts 1998; Betts et al. 2013; Garrard 1998; Garrard and Byrd 2013; Maher et al. 2016; Richter 2017; Richter et al. 2013; Rollefson et al. 2014; Rowan et al. 2017). We do this by presenting science-based archaeological evidence for wildlife presence, seasonal hunting opportunities and practices from ten chronologically varied prehistoric sites located in and around the Azraq Basin.

Despite the steady stream of archaeological fieldwork and research focused on the early prehistory of the Levantine steppes/deserts, it remains unclear whether these currently semi-arid to arid regions were only visited by hunter-gatherers on a seasonal basis in the Epipalaeolithic and Neolithic periods, or whether they could have sustained more prolonged, or year-round, occupation. This is the case with the north-east Jordan Badia, where some have viewed Neolithic sites in particular as being wet-season components of wider settlement systems based in the lusher Mediterranean zones (Köhler-Rollefson 1988; 1992; Quintero et al. 2004; Rollefson 2011), while others have argued for more autonomous systems with distinct traditions situated year round in the steppe (Baird 1994; Betts et al. 2013; Byrd 1992; Cropper 2011; Garrard 1998; Martin 1999). Concepts of this kind 
have also been discussed in relation to the earlier Epipalaeolithic (Byrd et al. 2016; Garrard and Byrd 2013; Maher et al. 2016; Richter et al. 2013).

The study presented here examines one of the underlying assumptions of the argument in favour of seasonal occupation of 'marginal zones' - namely that gazelle herds, a key resource underpinning hunter-gatherer presence, and also demonstrably important for later herders - were only seasonally available. Following this argument, the strong environmental seasonality and lack of perennial water sources would mean that reliable herd grazing, and thus richly resourced hunting grounds, would have been confined to winter and spring. As a consequence, gazelle herds would have migrated seasonally in and out of the Badia. This is the dominant model of gazelle herd mobility applied to the prehistory of this region, first proposed by Legge and Rowley-Conwy $(1987 ; 2000)$ in their influential model for the mid-Euphrates site of Abu Hureyra, which draws heavily on recent ethno-historical evidence for gazelle migrations.

The question of gazelle herd mobility is also integrally linked with on-going discussions regarding the chronology and functioning of desert 'kite' (hunting) structures in the Jordanian Badia, the greater Syrian Desert and into southern Arabia (Abu-Azizeh and Tarawneh 2015; Bar-Oz et al. 2011; Betts 2014; Betts and Burke 2015; Morandi Bonacossi 2014; Zeder et al. 2013). Most researchers reasonably presume that kite structures primarily targeted migrating gazelle herds (along with wild asses), and while there is evidence that some kites were constructed in the early Neolithic (PPNB, Abu-Azizeh and Tarawneh 2015), the dating of other major kite systems is still debated.

To date, researchers have been unable to empirically assess the validity of the gazelle migration model for the Jordanian Badia area in prehistory, although Tornero et al. (2017) have found zooarchaeological isotope evidence in support of seasonal mobility of gazelle populations in the Middle Euphrates valley, at a hypothesized northern point of migration. In this paper we address this key question through direct analyses of archaeological gazelle remains. Stable oxygen, carbon and strontium isotope data are used to provide indicators, respectively, of seasonal climate, diet and location. When retrieved from sequential enamel samples taken from archaeological gazelle teeth, they provide a time capsule, at seasonal resolution, covering approximately one year of early life. Dental microwear analysis of the occlusal surface of the same teeth provides data pertaining to the season of death, and thus of hunting.

Our overall aim is to gain a fuller understanding of the wildlife dynamics that underpinned prehistoric occupation of the Badia. We argue that the economic importance of gazelle herds to Epipalaeolithic and early Neolithic hunter-gatherers in the area, and even to early domestic livestock herders, is clear from the zooarchaeological record (Martin 2000; Martin et al. 2016), and therefore their presence in the landscape would have greatly influenced the seasonal patterns of human activity and duration of occupation. This research builds on that previously published, where we have presented our underlying model of isotopic indicators of likely seasonal gazelle herd mobility (Henton et al. 2018), and successfully tested it in a pilot study from one site Epipalaeolithic Kharaneh IV (Henton et al. 2017). The main focus of the current paper is to compare two periods in the Badia — the Early Epipalaeolithic and the Neolithic — which have yielded the most suitable 
gazelle tooth samples for analysis. A small number of preliminary results have been retrieved from the Natufian/ Pre-Pottery Neolithic A (PPNA) Shubayqa sites, but the limited sample size prevents us from proposing a reliable picture for these periods.

\section{Background}

\subsection{Archaeological research}

Archaeological research reveals occupation in areas of what is now the north-eastern Jordanian steppe-desert at stages through the late Upper Palaeolithic, the Epipalaeolithic and the Neolithic. Field research in this area has been conducted primarily under the banners of the Azraq Basin Project, the Black Desert Project, the Eastern Badia Archaeological Project and the Epipalaeolithic Foragers in Azraq Project (Betts et al. 2013; Garrard and Byrd 2013; Maher et al. 2016; Richter et al. 2013; Rollefson et al. 2014). In this region evidence suggests a diversity of technological traditions through the Epipalaeolithic, with some showing close similarities to those known from west of the rift valley and others to elsewhere on the Jordanian-Syrian plateau (Byrd and Garrard 2013; Richter and Maher 2013a). In addition, the antecedents of cultural change are shown to have been long established - for example, lithic trajectories in various occupations reveal Upper Palaeolithic roots to Epipalaeolithic bladelet and groundstone industries (Byrd and Garrard 1990; 2013); and the large Early Epipalaeolithic aggregation sites of Wadi Jilat 6 and Kharaneh IV presage Late Epipalaeolithic and Neolithic traditions with internally-divided structures, on-site burials, grave goods, symbolic caches and interaction trade spheres (Maher et al. 2012b; Richter and Maher 2013a; Richter et al. 2013). Later, in the Middle and Late PrePottery Neolithic B, when the full package of sedentism, plant cultivation and caprine management had appeared in more fertile areas of South-West Asia, hunting continued to be important alongside herding in the Badia (Garrard et al. 1996; Martin 1999). It should be noted, however, that there were breaks in the sequence in north-east Jordan and differences in evidence of occupation between the limestone areas to the west, the Azraq oases, the basaltic areas on the relatively well-watered flanks of Jebel Druze to the north, and the basaltic steppe to the east. With the exception of the PPNA, the limestone areas and Azraq oasis have evidence of occupation from most periods between the Early Epipalaeolithic and Late Neolithic. However, the basalt steppe to the east of Azraq has no evidence of occupation prior to the late Epipalaeolithic and also lacks the PPNA. The latter has only been found in the better watered basalt steppe in the northern Azraq Basin at Shubayqa (Betts 1998; Betts et al. 2013; Garrard and Byrd 2013; Richter 2017; Rollefson et al. 2014; Rowan et al. 2017).

\subsection{Palaeoenvironmental reconstruction}

Palaeoenvironmental reconstruction supports the concept that areas of the north-east Jordan Badia were very habitable during stages of the late Pleistocene and early Holocene. During the late Pleistocene some areas were periodically better watered and more lushly vegetated than today. Vegetation zones from the Late Glacial Maximum (LGM) onwards are modelled to follow an isohyet gradient from the more fertile north-west to the arid south-east, each zone penetrating further south-east along moister wadi margins than in the inter-fluvial areas (Byrd et al. 2016; Hillman 1996; Hillman in Moore 2000: 43-84). Although receding during drier episodes, permanent springs supporting marshland vegetation were present throughout the period in the central Azraq Oasis (Jones and Richter 2011). Furthermore, although broader regional climate data indicate cooler drier conditions during the LGM and the Heinrich 1 and Younger Dryas stadials, and warmer moister conditions in 
the Allerod-Bolling interstadial (Robinson et al. 2006), evidence from the Azraq Basin suggests that local conditions may have been at variance with this (Table 1). Thus, there may have been standing water in some of the western wadis at the end of the LGM, between $c$. 21-19 ka cal BP (e.g. in Wadi Kharaneh: Jones et al. 2016; Maher et al. 2012a), probably due to less-evaporative temperatures. Conditions subsequently became drier, although data from Wadi Jilat indicate localized marshland at c. 16-15 ka cal BP (Garrard and Byrd 1992; 2013). There is also evidence from Shubayqa in the northern Azraq Basin for relatively moist conditions during stages of the Younger Dryas (Richter 2017; Richter et al. 2017). Within the early Holocene moist conditions are well documented in the southern Levant between about 10-8600 cal BP (mid and late PPNB and early PPNC) (Goodfriend 1991; Migowski et al. 2006; Rossignol-Schick 1995; 1999; van Zeist et al. 2009). Locally wet conditions are attested from the eastern basalt region in the later Neolithic c. 8 ka cal BP (Rowan et al. 2017). In sum, there is evidence of persisting wetland locations offering refugia for humans and their prey in some areas of the north-east Jordan Badia during certain of the dryer periods (Martin et al. 2016; Ramsey et al. 2015).

\subsection{Gazella subgutturosa ethology}

As detailed below, gazelle remains dominate the wild mammal category at Azraq Basin sites considered in this study (Martin et al. 2016). While gazelle species identification is challenging for post-cranial material, horncore morphology does allow species assignation, and those from both Epipalaeolithic and Neolithic assemblages from the Badia (Martin 1998; Martin et al. 2010) are strongly suggestive of Gazella subgutturosa. Studies of modern G. subgutturosa show it to be highly adapted to steppe-desert habitats (Baharav 1981; Heptner et al. 1988: 618-22): meeting water needs within its food, selecting plants for moisture in arid summer months, and synchronizing births to springtime fluorescence of more nutritious annual grasses. The seasonal herd mobility and group dynamics of G. subgutturosa, however, is highly variable depending on its habitat and resource environment, unsurprising given its wide distribution. While it is locally extinct in the Jordanian Badia, the current distribution of G. subgutturosa ranges from northern Central Asia to southern Arabia, although recent genetic evidence finds two distinct clades, with Arabian/Middle Eastern populations distinct from Central Asian populations (Wacher et al. 2011). There is a proposal to rename the former as a separate species, Gazella marica (see also Murtskhvaladze et al. 2012). In large parts of northern Central Asia, G. subgutturosa makes longdistance seasonal migrations, leaving pastures in autumn, climbing into low mountains to avoid harsh winters and returning in spring (Derevyagin 1947). Thousands of animals can be seen on these migrations, moving distances of 600-1000 km, driven by the need to avoid snow cover (Zhevnerov 1984). Further south (e.g. Turkmenistan, Kazakhstan) only summer migrations are seen, with G. subgutturosa moving away from drying plains to better watered areas (Heptner et al. 1988).

The mobility of G. subgutturosa (cf. marica) in Arabia is harder to assess since most well-studied populations are impacted by living in protected, but mostly unfenced, areas (Cunningham and Wacher 2009). Here, habitats are gravel plains or sand-dune desert. Free-ranging herds are observed to roam long distances in search of forage; they are highly nomadic but not migratory (Cunningham and Wronski 2011). Rather, herds tend to aggregate and disperse within the same locality on a seasonal basis, as an adaptation to forage availability. Herd sizes - determined by rainfall and vegetation patch richness - are larger and more closely packed in winter, 
but still consist of less than 100 individuals in mixed herds, while only very small groups congregate in summer (Cunningham and Wronski 2011; Martin 2000).

G. subgutturosa's seasonal mobility shows it to be highly adaptive to specific environmental and ecological contexts; there is no fixed behaviour pattern for the species. Equally, animal seasonal mobility patterns can shift over time as ecological factors change, which includes human and livestock presence. Increased pastoralist presence in the Turan Protected Area in Iran forced Dorcas gazelle to shift distribution away from these competitors (O’Regan 1980); likewise, Leimgruber et al. (2001) show dramatic reductions in Mongolian gazelle distributions and corresponding shifts in their migration routes, resulting from over-harvesting and overstocking of livestock in the last century. These factors warn against drawing upon ethnohistorical observations of gazelle migrations in Syria and Transjordan from the 19th and 20th centuries for direct application to prehistory (e.g. Legge and Rowley-Conwy 2000; Zeder et al. 2013). While these studies provide many useful insights, wildlife mobility strategies for the late Pleistocene and early Holocene need to be reconstructed, rather than assumed.

As evidence points to the prehistoric Badia landscape being better watered and more lushly vegetated during certain periods than today (see above), it is possible that herds did not need to migrate but were more sedentary, only seasonally aggregating and dispersing, meaning they would have been present as a potential hunted food resource year-round. We have previously identified four likely patterns of gazelle seasonal mobility in and around the Badia (Henton et al. 2018). One pattern proposes more sedentary behaviour, with herds locally available to hunters year-round, while three include annual movement or migration, with herds only seasonally available (Fig. 1).

Pattern One assumes a less degraded and better-resourced landscape supporting localized seasonal aggregation and dispersal around water bodies (Cunningham and Wronski 2011).

Pattern Two draws on the seasonal cycle of observed Bedouin transhumant pastoralists and their flocks (Henry 1995: 371; Köhler-Rollefson 1992; Lancaster and Lancaster 1991), modelling westward up-stream movement along wadis in summer, seeking vegetation patches with longer growing seasons, before returning down-stream to the Oasis winter shelter.

Pattern Three describes Legge and Rowley-Conwy's (1987; 2000) widely accepted model of G. subgutturosa migration (Bar-Oz et al. 2011; Goring-Morris 1995: 156); it builds on the seasonal nature of hunting established through zooarchaeological analyses at Abu Hureyra, ethnographic accounts of gazelle mobility, and the orientation of desert kites assumed to be hunting traps in later periods (Betts 1985). This model proposes that the migration heads $600 \mathrm{~km}$ south, from well-watered spring birthing grounds on the Syrian Euphrates, to overwinter in the Azraq Basin.

Pattern Four, notes the increasing Early Holocene presence of Saharo-Arabian flora and fauna, possibly including the closely related G. marica (Tchernov 1997), and numerous desert kites along the length of the Wadi Sirhan route (Adams 1977; Barge et al. 2013). Noting the scattered water sources in the Middle Pleistocene (Breeze et al. 2016; Stimpson et al. 2016), Pattern Four models migration from summers spent in the cooler Azraq Oasis, along the $300 \mathrm{~km}$ corridor of the Sirhan depression, to overwinter in the warmer Nefud. 
These four-modelled patterns are clearly not exhaustive but are seasonal movements which can be identified with the approaches used in this study, and are thus testable, and can be employed heuristically.

\section{Case-study sites}

Our ten case-study sites, selected for the suitability of their zooarchaeological assemblages, are situated in and around the Azraq Basin of northern Jordan (Fig. 2). This endorheic basin (Bender 1974) drains towards the central Oasis (c. 520 masl), which is comprised of Quaternary gravel plains with (until recently) permanent spring-fed fresh-water marshlands and extensive mudflats (qas or playas) seasonally inundated with wadi runoff that soon evaporates becoming saline (Ames and Cordova 2015). To the west/south-west, Early Tertiary limestone plains grade into hills incised by wadis draining from the watershed that separates the drainage catchment from the western Cretaceous limestone Jordanian Highlands (c. 850 masl). Winter-run-off collects in wadi, qas and deeper channels before evaporating, or making its way to the central Qa el-Azraq. Pliocene Basalt boulder fields, also incised by wadi systems draining from the Jebel al-Druze, cover the north/north-eastern sector and groundwater from this region is the main contributor to the Oasis springs (United Nations Development Programme 1966).

The three geological areas are each notable for their homogeneity, each with lightly rolling topography or extensive plains, occasionally incised by ephemeral water courses.

We targeted sites from across the main geological areas and from two key periods: The Early Epipalaeolithic (EEP) and the Pre-Pottery Neolithic B (PPNB) to later Neolithic (LN). It should be noted that although the limestone areas in the western Basin, and the Azraq oasis at its centre, have occupational evidence from both periods, the basaltic regions to the north and east have no evidence of occupation from before the late Epipalaeolithic (LEP) (Betts 1998; Betts et al. 2013; Garrard and Byrd 2013; Richter 2017; Rollefson et al. 2014; Rowan et al. 2017). We use broad analytical groupings of sites, although timespans vary considerably. There are two Early Epipalaeolithic analytical cohorts, Kharaneh IV and Wadi Jilat 6 Upper Phase (KHIV/WJ6) in the western drainages of the limestone steppe and Ayn Qasiyya (AQ) within the Azraq Oasis. The PPNB and later Neolithic sites include Wadi Jilat 13 (WJ13) in the limestone steppe, Azraq 31 and Bawwab al-Ghazal (AZ31/BG) in the Oasis, Dhuweila (DH) close to the edge of basalt fields to the east of Azraq and 'Ain Ghazal (AG) which lies to the west of the Azraq Basin in the Jordan Highlands. We also include preliminary results from the Late Epipalaeolithic and Pre-Pottery Neolithic A (PPNA), although the samples are very small. These are from the Natufian site of Shubayqa 1 and its close neighbour, the PPNA and early PPNB (EPPNB) site of Shubayqa 6 (SH1/SH6) in the basalt to the north of Azraq on the flanks of Jebel Druze.

For each site, location, local environment, size, dating, material culture and economy are summarized in Table 2 (with references therein). Key points to note are that all sites overlook seasonal or persistent water bodies and none, apart from those in the Azraq Oasis and at Dhuweila, are in areas currently drier than the present steppe/desert boundary (100 mm isohyet). Two are in seasonally well-watered areas — Shubayqa c. 150-200 mm and 'Ain Ghazal c. 250-300 mm isohyets. Early Epipalaeolithic sites are typically located in the western 
drainages of the Tertiary Limestone steppe or beside the Oasis wetlands. They fall into two size categories; huge aggregation sites with evidence of dwelling structures in the western wadis, and ephemeral hunting camps at Azraq. Later sites, from the Natufian and Early Holocene, which include hunting camps and, in the case of the Neolithic, also include seasonal hunter-herder-cultivator settlements, are more dispersed and smaller, and two are in more ecotonal (isohyets $>150 \mathrm{~mm}$ ) settings, including the basalt steppe. The multi-period PrePottery/Pottery Neolithic settlement of 'Ain Ghazal is by a spring in the Jordanian Highlands to the west of the Azraq Basin.

Long-term zooarchaeological research provides information on the animal-based subsistence in the Badia (Fig. 3 and references therein). Focusing on the gazelle (black) and caprines (white), it can be seen that throughout the Epipalaeolithic gazelle was the main hunted taxon in the area (c. 70\% NISP). In the Neolithic, gazelle proportions are lower in assemblages where herded caprines are also present (e.g. Wadi Jilat 13, gazelle are $c$. $20 \%$ ), but are still present in extremely high proportions at Dhuweila (90\%), which is a specialized hunting camp in the basalt steppe (Betts 1998). The only permanently settled village site in our sample is Neolithic 'Ain Ghazal in the Jordan Highlands, where herded caprines make up 65\% of the Middle PPNB assemblage, rising to $>70 \%$ in the Transitional Middle PPNB/Late PPNB, and gazelle representation falls to <10\% NISP. Some faunal assemblages are rich in other taxa, for example waterfowl are common at Shubayqa 6, while wild cattle and equids dominate at Azraq 31. The zooarchaeological evidence so far produced for hunting seasonality (Table 3) draws on the presence of seasonally migrant species, gazelle epiphyseal fusion data, to a lesser extent gazelle dental eruption and wear data, and also dental cementum studies. As Table 3 shows, prior to the present study, evidence most commonly showed autumn/winter gazelle hunting.

\section{$4 \quad$ Methods}

\subsection{Underlying methodology}

In this research two datasets are used to allow insights into two periods during the life of each gazelle: over approximately one year early in life, and a few weeks before its death. Methodological principles underlying the archaeological application of stable isotope and dental microwear analyses as environmental indicators (especially those retrieved from ungulate dental enamel, as used here) have been extensively discussed in detail and applied with some success in Henton et al. (2017; 2018). Accordingly, the principles are outlined only briefly here.

For our isotopic datasets, ungulate enamel development in mandibular molars allows sequential sampling up the length of the tooth at $c$. bi-monthly resolution (Fig. 4A) over an approximate one-year time capsule within juvenile/sub-adult life (Balasse 2002; Fricke and O’Neil 1996; Kohn et al. 1998; Munro et al. 2009), such that sequential sequences can be constructed into curves and interpreted in terms of seasonal changes in climate, vegetation and location (Figs 4B-D) (Bentley 2006; Bryant and Froelich 1995; Cerling and Harris 1999; de Niro and Epstein 1978; Henton 2012; Henton et al. 2017; Sillen et al. 1998; Tieszen 1991). 
Oxygen isotope results most usefully provide seasonality information relating to approximately one year in the gazelle's life and to the season of birth. They contribute to interpretation of climate, water and food resources and to movement strategies. Higher $\delta^{18} \mathrm{O}$ is associated with hotter, dryer seasons and lower values with cooler, wetter times of year (Dansgaard 1964; Rozanski et al. 1993). Carbon isotope results provide information on the same season as the oxygen data as both datasets derive from the same carbonate deposits. Curves show changing dietary balance between plants with $\mathrm{C}_{3}$ (lower $\delta^{13} \mathrm{C}$ ) and $\mathrm{C}_{4}$ (higher $\delta^{13} \mathrm{C}$ ) photosynthetic pathways (Bender 1971; Ehleringer et al. 1997; Vogel et al.1986). In the Badia gazelle diet, we can expect the spring/early summer flush of annual grasses to give lower $\delta^{13} \mathrm{C}$, becoming higher throughout summer and autumn as water-stress increases in $\mathrm{C}_{3}$, annuals die-off and arid-adapted $\mathrm{C}_{4}$ plants increasingly dominate.

Strontium isotope results provide information over the same length of time as the carbonates from the same samples, but a greater lag in strontium uptake into enamel means that the portrayed strontium seasonality does not directly match that for carbonates (Montgomery et al. 2010). Strontium readings provide information on labile strontium ingested with food; as this is primarily derived from the underlying geological substrate (Faure and Powell 1972; Graustein 1989), gazelle location can be tracked. Variation in rainfall in different climatic periods results in differing contributions to the mix of waterborne sediments and airborne loess brought in, respectively, from upstream and on south-easterly prevailing winds. However, such variation is not at a scale that would be recorded within the time capsule captured in the gazelle tooth enamel, and so can be discounted when investigating simple annual seasonal movement over different geological substrates and through fringe areas where there is a mix of contributory materials.

These isotopes can provide useful information on the environmental signatures of location and season in the Badia for the following reasons. Firstly, modern isotopic values in the Badia can be related to the seasonality of past environments because storm track directions (Enzel et al. 2008), the Irano-Turanian vegetation communities (Batanouny 2001; Colledge 2001), and the main geologies are largely unaltered. Secondly, seasonal climate differences are such that oxygen isotope ratios $\left(\delta^{18} \mathrm{O}\right)$ can discriminate season; differences in composition and metabolism of seasonal plant communities allow carbon isotopic ratios $\left(\delta^{13} \mathrm{C}\right)$ to identify seasonal vegetation; and key geological differences in the Badia (Cretaceous limestone, Tertiary limestone/Quaternary gravels and Basalt) produce isotopic signatures of labile strontium $\left({ }^{87} \mathrm{Sr} /{ }^{86} \mathrm{Sr}\right)$ that identify location (see isotopic values recorded in Figs 4 and 5).

In our focused baseline (Balasse et al. 2002; Bogaard et al. 2014; Britton et al. 2009; Hoppe et al.1999; Julien et al. 2012) Henton et al. (2018) used oxygen, carbon and strontium isotope data to model the season, the seasonal vegetation and the main geological substrates of the Badia. Using these, we developed isotopic models for each proposed gazelle mobility pattern outlined in Section 2.3 (Fig. 5). It is the shape of each isotopic curve in our mobility model that is of key interest, illuminating progressive changes throughout seasons and across varied geological substrates; our research objectives do not require high resolution.

In the research presented in this paper we compare annual isotopic sequences in gazelle teeth to the annual sequences modelled for the four mobility patterns outlined above. The comparisons allow us to infer seasonal 
gazelle presence in the vicinity of prehistoric occupation sites. A degree of time-averaging of all isotope readings in gazelle enamel can be expected due to sampling precision and overlapping enamel formation, and consequently all readings in tooth enamel would be dampened compared to those expected at that time in the environment. Once again, it is the shape of each isotopic curve that is of key interest, illuminating the annual cycle of progressive changes experienced by the gazelle throughout seasons and across varied geological substrates.

Turning to our second dataset — dental microwear — indicators of dietary regime preceding death are provided by dental microwear analysis (DMA) of ephemeral marks on the occlusal surface of the same teeth (Fig. 4E). A 2-feature discrimination of pits and striations usefully separates grazers from browsers (Solounias and Hayek 1993; Solounias and Moelleken 1992) and the rapidity of feature turnover allows a bimodal distribution in seasonally mixed feeders (Merceron et al. 2007; Rivals et al. 2011). Gazelle are mixed feeders with a preference for late winter/early summer grasses, and the most palatable arid-adapted non-grasses in summer/autumn. Thus, dental microwear of archaeological gazelle specimens distinguish deaths (by hunting) in these two parts of the year.

The approach we present in this paper has been successfully tested in our pilot study of one site, Kharaneh IV (Henton et al. 2017). We assume seasonal mobility patterns for sampled individuals to be representative of those of whole herds, and patterns to represent annually repeated movements where environmental pressures are largely unchanged. The strength of our approach lies in the combined interpretation of data constrained by gazelle ethology and palaeoenvironmental reconstruction (see sections 2.3 and 2.2 respectively).

\subsection{Materials}

The materials and results discussed below are retrieved from the ten case-study sites outlined above. Over 400 medium-sized ungulate tooth specimens were sampled from previously studied zooarchaeological assemblages retrieved from secure contexts and given an assemblage extraction number; most were single teeth, some were tooth rows. Those securely identified as gazelle second or third mandibular molars, free from abrasion, fracturing or concretion, were selected for analyses and given an analytical specimen number (Appendix 1); it is this numbering system that is used from here on.

Only 91 teeth were suitable for analyses due to poor depositional environment: 60 third mandibular molars $\left(\mathrm{M}_{3}\right)$ and 31 second mandibular molars $\left(\mathrm{M}_{2}\right)$. A single specimen (an $\mathrm{M}_{3}$, Specimen 1 from Wadi Jilat 13) was later identified as a sheep; the remainder were confirmed as gazelle. Each tooth specimen generally represents an individual animal, but in 11 cases, both second and third mandibular molars from one individual were sampled. For each specimen, its condition and tooth-wear stage were recorded (following Munro et al. 2009), dental metrics were taken where possible (Appendix 2), and a photographic record made (details on UCL Discovery, forthcoming).

\subsection{Analyses}


Selected teeth were prepared for analyses: firstly, casts were made by non-destructive procedures for image capture of dental microwear and; secondly, six enamel samples from each tooth were destructively drilled for $\delta^{18} \mathrm{O}, \delta^{13} \mathrm{C}$ (carbonate) and ${ }^{87} \mathrm{Sr} /{ }^{86} \mathrm{Sr}$ isotope analyses. Methods used for retrieval and preparation follow established procedures: for dental microwear analysis (DMA) (Mainland 1998; Ungar 2002), and for isotopes (Balasse 2002). At UCL, microwear images were captured in the Institute of Archaeology SEM and Analysis Suite and carbonate isotopes analyzed at the Bloomsbury Environment Isotope Facility; strontium was analysed at either UL Royal Holloway College Isotope Geochemistry Laboratories or University of Bristol School of Earth Sciences.

\section{$5 \quad$ Results}

Occlusal surfaces of 77 teeth produced good DMA images, but many teeth fractured on drilling, reducing those available for ${ }^{87} \mathrm{Sr} /{ }^{86} \mathrm{Sr}$ isotope analysis to 61 , and carbonates to 49 ; multiple sampling of each tooth produced a total of 184 carbonate and 205 strontium samples for analysis (Table 4 and Appendix 3). Pearson and Grove (2013) demonstrate that sample sizes of nine specimens can provide robust analyses for isotopic interpretations, while for DMA a sample size of 14 is advised (Mainland pers. comm.). These targets are met for the Early (EEP) cohorts but fall short for the others, especially Shubayqa. At times, therefore, interpretation is limited, although significance is tested in comparisons of key interest to research questions.

\section{$5.1 \quad$ Isotopes}

Taking isotope results first (Appendix 4) external reproducibility of BEIF laboratory analyses is \pm 0.04 and \pm 0.08 for $\delta^{13} \mathrm{C}$ and $\delta^{18} \mathrm{O}$ respectively. For ${ }^{87} \mathrm{Sr} /{ }^{86} \mathrm{Sr}$ it is $\pm 0.000014(2 \sigma)$ for the samples taken from 33 teeth analysed at RHUL and $\pm 0.000016(2 \sigma)$ for those from the 28 analysed at Bristol. An international standard applied to the two latter datasets calibrates readings and confirms results consistency (further details on UCL Discovery, forthcoming). The range of $\delta^{18} \mathrm{O}$ results $(9.03 \%$ to $-6.19 \%$ on the PDB scale) falls within that for Azraq $\delta^{18} \mathrm{O}$ in modern precipitation after adjusting for body tissue incorporation fractionation; that for $\delta^{13} \mathrm{C}$ (2.10 to $-13.36 \%$ ) fits within the range seen in gazelle feeding ethology after fossil fuel and tissue incorporation fractionation adjustments; and the ${ }^{87} \mathrm{Sr} /{ }^{86} \mathrm{Sr}$ range (0.708396 to $0.707627 \%$ ) falls within local geological parameters (see Henton et al. 2017; 2018 for details).

Three archaeological gazelles have oxygen, carbon and strontium isotope results for both $\mathrm{M}_{2} \mathrm{~S}$ and $\mathrm{M}_{3} \mathrm{~s}$ (Fig. 6). In Gazella gazella, $\mathrm{M}_{2}$ tooth growth occurs between two and seven months, whereas the $\mathrm{M}_{3}$ growth is later between nine and 14 months (Munro et al. 2009). Comparison of the two curves shows the isotopic curve expression of this enamel developmental sequence to be clearly visible, suggesting that G. subgutturosa have a similar developmental pattern. This is instructive, allowing evidence from the curves of both teeth to be discussed together, and addressing many shortcomings arising from truncated records in worn specimens. For each analytical cohort (Figs 7-13), curves generated from the sample sequence in each tooth $\left(\mathrm{M}_{2} \mathrm{~s}\right.$ on the left and $\mathrm{M}_{3} \mathrm{~S}$ on the right) are displayed with $\delta^{18} \mathrm{O}$ in the top row, $\delta^{13} \mathrm{C}$ in the middle, and ${ }^{87} \mathrm{Sr} /{ }^{86} \mathrm{Sr}$ at the bottom. A light line links data retrieved from $\mathrm{M}_{2} \mathrm{~s}$ and $\mathrm{M}_{3} \mathrm{~s}$ in the same jaw. 
Dental microwear analysis was completed for $52 \mathrm{M}_{3} \mathrm{~s}$ and $25 \mathrm{M}_{2} \mathrm{~s}$ (Appendix 5) (further details on UCL Discovery, forthcoming). The results for all specimens are displayed plotting total feature numbers against percentage striations (Fig. 14). The highest striation percentage is $83 \%$ and the lowest $13 \%$. Diets rich in fibrous grasses are identified by a striation $\%>50 \%$, while diets rich in soft browse of tree leaves and forbs by a striation count $<50 \%$. The variation is in keeping with the seasonal mixed-feeder behaviour of gazelle. Although striation numbers increase in $\mathrm{M}_{2} \mathrm{~s}$ compared to $\mathrm{M}_{3} \mathrm{~s}$ in the same tooth row, these might be offset by additional grit ingested by arid environment ground feeders such as gazelle (Rivals et al. 2011).

For each analytical cohort (Fig. 15), DMA results are presented with a kernel density plot showing specimens grouped (5\% kernel size) by distribution of striation proportions. The left-hand columns (white) include all specimens showing soft, browse-rich diets, the right-hand columns (black) show fibrous, grass-rich diets.

\section{$6 \quad$ Interpretation - observed trends}

To create a clear interpretation from the wealth of data presented here, we first discuss the results from each dataset in general terms, drawing out observed trends that can be readily established. The results for each gazelle isotope dataset are displayed by individual site cohort in Figs 7-13; results for the microwear for all gazelle in Fig. 14; and mean results for each site cohort in Fig. 15 for microwear and Fig. 16 for isotopes. In the following interpretive section, we will consider each analytical site cohort, and make some preliminary spatial and chronological comparisons that we test statistically. We discuss identified trends and differences before considering what we can add to the discussion on underlying factors contributing to landscape use of the Badia during the Epipalaeolithic and Neolithic.

\subsection{Oxygen isotope results}

The seasonal weather differences experienced by each studied gazelle specimen throughout an approximate year can be interpreted from the oxygen data presented in the top row of charts for each site cohort (Figs 7-13). Reading from left to right, seasonal differences, as marked by curve amplitude, are apparent in most specimen curves. Seasonality is greater in specimens from some cohorts (AQ (Fig. 8), KHIV/WJ6 (Fig. 11) and SH1/SH6 (Fig. 12) specimens) and less in others (AG (Fig. 7) and AZ31/BG (Fig.9)). Seasonal differences, as exhibited in absolute values, show hotter (SH1/SH6 (Fig. 12)) and cooler (AG (Fig. 7)) summers, but less winter variation. Of the outliers, some have flat, non-seasonal curves (AG sp37 (Fig. 7)); others have seasonal curves that are very low (AQ sp15 (Fig. 8) and AZ31/BG sp64 (Fig. 9)) or high (AZ31/BG sp77 (Fig. 9)). Close clustering of curves is most notable in gazelle from AG (Fig. 7) and KHIV/WJ6 (Fig. 11). This points to gazelle from each cohort living in very similar conditions, probably, therefore, in close proximity to each other. Clustering is also apparent, but looser, in the other sites.

In all specimen curves, bar one, higher $\delta^{18} \mathrm{O}$ and lower $\delta^{18} \mathrm{O}$ values emerge at roughly the same height up the tooth column, i.e. at a similar time in enamel formation; these gazelles were born in the same season. The exception, WJ6 sp42 (Fig. 11), has an oxygen isotope curve half a cycle out of sync, it was born six months apart. 


\subsection{Carbon isotope results}

The seasonal differences in food intake for each studied gazelle specimen can be interpreted from the carbon data presented in the middle row of charts for each site cohort (Figs 7-13). Reading from left to right, seasonal food differences, as marked by curve amplitude, are apparent in most specimen curves. There is no indication of seasonal movement, for example into wetlands or uplands, where the curve shape might be altered by difference in length of growing season or in water-stress. Therefore, it can be proposed that variety in food intake was due to seasonal differences; this is consistent with gazelle seasonal mixed feeder ethology. This is clearest in the same analytical cohorts as for oxygen (AQ (Fig. 8), KHIV/WJ6 (Fig. 11) and SH1/SH6 (Fig. 12) where, again, clustering is close, suggesting all gazelle were feeding in very similar, if not the same, feeding grounds. Curves for other site cohorts (AG (Fig. 7) and AZ31/BG (Fig.9)) are again less clear; but all show some seasonality and loose clustering.

Specimens from AG (Fig. 7) and WJ13 (Fig. 13) have summer (high) and winter (low) $\delta^{13} \mathrm{C}$ values that are similar. This is evidence of non-extreme seasonality and is consistent with cooler upland vegetation richer in $\mathrm{C}_{3}$ plants. The curve shapes in two outliers, AG sp37 (Fig. 7) and AZ31/BG sp77 (Fig. 9), echo those in their oxygen curves, linking vegetation patterns to water and temperature during that year. Again, WJ6 sp42 (Fig. 11) has a reverse curve consistent with a different birth season.

\subsection{Strontium isotope results}

The seasonal differences in location for each studied gazelle specimen over an approximate year can be interpreted from the strontium data presented in the bottom row of charts for each site cohort (Figs 7-13). Reading from left to right, the curves show that nearly all the gazelle remained on one geological substrate in both Epipalaeolithic and Early Holocene specimens. Results from each cohort tend to cluster, most apparently in specimens from KHIV/WJ6 (Fig. 11), WJ13 (Fig. 13) and DH (Fig. 10), this lends support to the premise that herds remained within a relatively restricted range. With no evidence of movement to another geological context, this strongly suggests that gazelle were living all year round, within limited regions, and feeding on seasonal vegetation. Although extensive movement within one geological region is invisible in terms of the analytical data, it is ethologically unlikely that gazelle would expend energy in moving any great distance between locations offering similar possibilities, because doing so would not offer the benefit of changing resource availability. Movement over one geological substrate might be invisible if gazelle moved too rapidly to feed; they commonly, however, move steadily between resource patches unless predation forces flight.

There are a few exceptions where gazelle specimens have ${ }^{87} \mathrm{Sr} /{ }^{86} \mathrm{Sr}$ values that change throughout the analysed period — notably in Specimen 51, an M2 from KHIV (Fig. 11) and in Specimen 91 (M2) and 84 (M3) from the same SH1 gazelle (Fig. 12). This is interpreted as a change in the source of labile strontium contribution to the diet, related to changing underlying geology, as shown by Henton et al. (2018). We argue that in these cases animal movement over different geological areas is apparent, however they progress in different patterns and time frames. Strontium data from the gazelle with both second and third molars analysed, SH1 sp91/sp84 (Fig. 
12), provide a complete annual cycle. The curve generated from the data, read from left to right, shows a rise in strontium isotopic values consistent with an increasing contribution of Tertiary limestone/Quaternary derivation. It appears that the gazelle moved from basalt to Tertiary limestone/Quaternary gravel, but as this takes a whole year to complete, the strontium curve does not identify an annually repeated seasonal movement pattern. None of the other outliers (KHIV/WJ6 sp51 (Fig. 11), AQ sp6 (Fig. 8), DH sp70 (Fig. 10) and AZ31/BG sp77 (Fig. 9)) have data that cover a whole cycle, so seasonal patterns of movement cannot be proposed.

The ${ }^{87} \mathrm{Sr} /{ }^{86} \mathrm{Sr}$ values, as expected given the retrieval site locations, indicate that gazelle from AZ31/BG (Fig. 9) and KHIV/WJ6 (Fig. 11) have year-round ${ }^{87} \mathrm{Sr} /{ }^{86} \mathrm{Sr}$ values for Tertiary limestone/Quaternary gravels and AQ specimens have a small basalt contribution. But, the ${ }^{87} \mathrm{Sr} /{ }^{86} \mathrm{Sr}$ values in gazelle from other sites do not as closely match those of their retrieval site geological substrate; these results are puzzling and are briefly outlined here before further discussion in section 7. Gazelle hunted from AG (Fig. 7) in the Cretaceous limestone highlands have year-round Tertiary limestone signatures; those from basalt sites DH (Fig. 10) and SH1/SH6 (Fig. 12) have a Tertiary limestone/basalt mix; and gazelle from WJ13 (Fig. 13) on the Tertiary limestone have mixed ${ }^{87} \mathrm{Sr} /{ }^{86} \mathrm{Sr}$ values, consistent with the nearby Tertiary limestone/Cretaceous highlands.

\subsection{Dental microwear results (DMA)}

Information on seasonal dietary intake in the days preceding death can be interpreted from the dental microwear. DMA provides information on the end of the gazelle's life, giving the season when each was hunted. Gazelle pre-death grass diets produce microwear rich in striations; those rich in browse have more pits. Again, gazelle ethology and Badia vegetation seasonal distribution allow signatures to be equated with deaths in, respectively, late winter/spring/early summer and the rest of the year. The distribution of results for the whole cohort allows the hunting seasons at each occupation site to be proposed.

Overall, results (Fig. 14) for all studied gazelle specimens show the season of death to be evenly distributed, with only a slight bias towards more deaths in the grass-rich season (late winter to early summer). The overlapping field boundaries enclosing gazelle from each site cohort, suggest that each site, bar one (see below), hunted in more than one season, consistent with herds being available year-round rather than being seasonal migrants. However, despite year-round availability, each site cohort has a preferred hunting season (Fig. 15). In most site cohorts the majority of gazelle have DMA that indicate a grass-rich bias to their diets at death consistent with being hunted in late winter/ spring/early summer. In contrast to this general pattern, the most marked seasonal DMA is AG where all gazelle died in one, different, season on the browse-rich diets associated with late summer/ autumn/early winter.

\section{$7 \quad$ Interpretation - chronological and spatial trends in analytical cohorts}

Four important statements can be made following the interpretations of the datasets:

a. The seasonality evidence from the oxygen and carbon isotope results strongly indicate that most gazelle were born in the same season, which is in keeping with the modelled seasonality of the climate and associated resources in the Badia. Gazelle ethology points to springtime when conditions and resources are optimal for nursing mothers and their young; autumn births occur rarely. 
b. The location evidence from the strontium results show that gazelle were not feeding over different geological substrates throughout the year. Support for this supposition is provided by the uninterrupted carbon and oxygen seasonality curves apparent in most specimens, as well as the DMA evidence of hunting occurring in most seasons. This is consistent with our first mobility pattern of localized aggregation and dispersal, and does not support the three seasonal migration patterns.

c. The clustering of isotope results by site suggest that herds were not widely dispersed, but were grouped in and around quite localized feeding grounds, and were possibly members of discrete herds. Whilst results indicate that some of these herds were probably located in the vicinity of the occupation sites where, presumably, their hunters were based, this is not true of other site cohorts.

d. The dental microwear results are consistent with gazelle being seasonally mixed feeders. Whilst the gazelle died (were hunted) in all seasons, there is a slight emphasis on deaths being in the late winter/early spring season rich in annual grasses. This emphasis varies between cohorts but is reversed completely in the Neolithic village in the Jordanian Highlands.

In short, the evidence strongly suggests that gazelles, in those areas of the Badia from which samples were obtained and for the Epipalaeolithic and Neolithic phases for which there was data, were adapted to remain year-round in a well-resourced landscape.

Interpretation continues below with chronological and spatial comparison of site cohorts, where we extrapolate from the individual animals (represented by sampled specimens) discussed so far, to wider gazelle herd behaviour, particularly in response to human settlement. The following discussion refers to summaries of DMA (Fig. 15) and zooarchaeological seasonality interpretation (Table 3) and an additional chart showing the average maxima, minima and ranges for the isotopes for the Early Epipalaeolithic and PPNB/Later Neolithic site cohorts (Fig. 16); these exclude outliers and those with short curves, and do not include results from the Late Epipalaeolithic.

To validate our conclusions statistically we performed Student's two-sample $t$-tests on selected cohorts of sites. The tests compared the mean isotopic values of individual specimens, excluding those we judged to be outliers (specimen numbers 1, 6, 7, 15, 27, 37, 38, 51, 62, 64, 66, 70, 77, 80, 81, 87 and 91). The cohorts are compared, and the results of the statistical testing are summarized in Table 5 and Appendix 6 . An $F$-test for equality of variances indicated that for two comparisons the variances were not equal, therefore for these we used Welch's variant of the $t$ test. We considered pairs of cohorts in which the $t$-test returned a $p$ value of less than 0.05 to be statistically significantly different. All statistical tests were performed in the R statistical computing environment (R Core Team 2018: v. 3.5.1).

\subsection{Early Epipalaeolithic sites}

Kharaneh IV and Wadi Jilat 6 (Upper Phase) have extensive occupations dating between 20.0-18.7 ka cal BP, Ayn Qasiyya is slightly earlier. They are located beside wadis or water-bodies that could have held water yearround. KHIV and WJ6 are large aggregation sites, whereas AQ is described as a periodically occupied hunting 
camp, however, results show many similarities, such as, defined seasonality. Both have robust sample sizes allowing relatively secure interpretation.

Strontium signatures for both cohorts show very limited herd mobility throughout the year, but are quite distinct $(\mathrm{T}=6.7165, \mathrm{p}=<0.001)$, as expected from their geological location. KHIV and WJ6 are only $25 \mathrm{~km}$ apart, while AQ is $40 \mathrm{~km}$ east of KHIV and $60 \mathrm{~km}$ north-east of WJ6. This difference provides further support for the idea that gazelle herds were locally discrete rather than forming large herds that moved across the whole area. KHIV/WJ6 have closely clustered, smooth signatures, whereas those from AQ are clustered but more varied, probably due to the multiple vegetation and water sources in the Oasis: both show DMA evidence of hunting in more than one season, but with a marked bias towards grass-rich seasons. At KHIV/WJ6 this concurs with cementum evidence, but gives a stronger signature for spring hunting than that derived from epiphyseal fusion data. At AQ, an early summer hunting season agrees with zooarchaeological data that points to hunters targeting juveniles; now confirmed by the oxygen isotope data to have been spring born.

In summary, the evidence points to stable herds maintaining their ranges close to water sources, withstanding hunting in all seasons and, at AQ, maintaining a viable population size even when large juvenile numbers were killed. It appears that the Early Epipalaeolithic gazelle herds of the western drainages of the Badia (in the limestone region) and in the Azraq oases provided ample resources for hunter-gatherers who, throughout the period, used the area in different seasons.

\subsection{Early Holocene sites}

Dhuweila is a Late PPNB/Late Neolithic site described as a specialist hunting camp (Betts 1998). It is situated on a spur overlooking the Qa Dhuweila on the basalt fringes $c .40 \mathrm{~km}$ to the north-east of the oasis. The LPPNB dates from 9.5 to $9.0 \mathrm{ka}$ cal BP, the Late Neolithic from 8.4 to $7.7 \mathrm{ka} \mathrm{cal} \mathrm{BP}$. Carbonate isotopes identify rather restricted climatic seasonality compared to earlier sites, but with similar vegetation seasonality and, for most sampled specimens, strontium isotopes once again cluster closely with flat signatures indicative of one geological substrate and probably with only minimal local movement likely throughout the year. The strontium signal places that location within the Tertiary limestone/Quaternary gravels, whereas a mixed basalt and Tertiary limestone/Quaternary gravel signature local to Dhuweila would be expected. The simplest explanation is that herds lived down on the Tertiary limestone/Quaternary gravels steppe $c .15 \mathrm{~km}$ to the south of the site. It is possible that they were hunted there and then the whole carcasses carried to the site. A more likely explanation, given the number of new-borns and very young juveniles (Martin et al. 2016), is that whole herds were driven nearer the site. DMA points to multi-seasonal hunting, only slightly biased towards spring/early summer; this accords with zooarchaeological evidence, and with Dhuweila being a specialist hunting camp.

Azraq 31 and Bawwab al-Ghazal are short-lived LPPNB and early Late Neolithic sites located in the Oasis near the earlier AQ hunting camp and interpreted as possibly being early hunter-herder camps. Compared to AQ, oxygen isotope signatures indicate more arid weather conditions throughout the year $(\mathrm{T}=-2.8653, \mathrm{p}=0.017)$ with slightly more reliance on $\mathrm{C}_{4}$ arid-adapted vegetation and slightly less input from basalt-derived labile strontium. However, this climate signature is not consistent with a warmer, moister early Holocene climate; it is more 
feasible that gazelle herds were inhabiting areas in more arid Tertiary limestone steppe, away from oasis resources. DMA evidence points to diets at death being richer in summer arid-adapted browse than the earlier AQ site. This might signal that herders who settled close to the oasis waters in summer were taking advantage of gazelle herds which now mostly roamed on the nearby steppe, only moving to the oasis during the summer to feed on longer-lasting forage in this wetter location.

Wadi Jilat 13 is an early Late Neolithic settlement, occupied intermittently c. 9.0-8.5 ka cal BP and located on Tertiary limestone/Quaternary deposits near the Epipalaeolithic WJ6 aggregation site. There are indications from bead-making, as well as ritual paraphernalia, that the site had a specialized role (Garrard et al. 1994; Wright et al. 2008). The presence of chaff in the small archaeobotanic domesticate assemblage suggests the occupation season was long enough for small-scale or opportunistic cultivation (Colledge 2001). The occupants also raised domestic caprines while continuing to hunt gazelle. Compared to KHIV/WJ6, the sampled gazelle from Wadi Jilat 13 show a considerably more constricted diet, feeding year-round on a $C_{3} / C_{4}$ dietary mix without the same spring/early summer access to $C_{3}$ grasses $(T=-2.1672, p=0.049)$. In addition, the strontium results show the gazelle to have been living year-round in a location with a noticeably greater Cretaceous limestone contribution than the occupation site $(\mathrm{T}=-8.6851, \mathrm{p}=<0.001)$. If correct, this echoes findings for $\mathrm{DH}$, AZ31 and BG where herds were not migrating seasonally, but appear to have primarily inhabited, year-round, areas at some distance from the sites where their carcass parts were retrieved. Interestingly, Specimen 1 from Wadi Jilat 13, which was identified as a domestic sheep rather than gazelle, remained on Tertiary limestone/Quaternary gravels, providing a clue as to herder mobility. The sheep's flat, local strontium signature suggests it did not move to a different geology throughout the year and was, therefore, not part of a seasonally transhumant flock. If domestic caprine herds were pastured in the general area for extended seasons, we might propose that human and livestock activity had displaced gazelle herds, possibly upstream towards the Cretaceous geology only $7-12 \mathrm{~km}$ to the west. This would perhaps have seen hunting parties going further afield to procure gazelle. The DMA interpretation of hunting seasonality suggests hunting was multi-seasonal, which supports the picture of extended seasons of site occupation.

'Ain Ghazal is a large, multi-period Neolithic village site located to the west of the Azraq Basin in the Jordanian Highlands. Specimens have been retrieved from various periods between the Middle and Late Pre-Pottery Neolithic (MPPNB) and the Yarmoukian (Late Neolithic), dating between 10.1-8.0 ka cal BP. At its height in the PPNB, occupation is thought to have been permanent, but there are indications of more intermittent occupation subsequently (Rollefson 2015). The lower oxygen isotope signatures $(\mathrm{T}=3.3036, \mathrm{p}=<0.002)$ and, to a lesser extent, those of the carbon isotopes, reflect this cooler, better-watered setting where annuals have a longer growing season. Strontium isotopes suggest that gazelle herds remained on one geological substrate year-round, but in a Tertiary limestone location, at least $17 \mathrm{~km}$ to the east, on the western slopes of the Azraq Basin. Once again, gazelle herds seem to have been displaced by settled human activity and a mixed farming economy, including dominant caprine herding (von den Driesch and Wodtke 1997). 'Ain Ghazal gazelle specimens show a strong DMA bias towards browse-rich diets. In this upland setting, an extended season of browse-rich vegetation is unlikely, and as gazelle herds are some distance from the settlement there would be no direct competition for grass-rich resources from domestic herds. Consequently, it appears likely that hunting was 
strongly seasonal, taking place between late summer and early winter, but not during spring. This interpretation accords with the zooarchaeological interpretation and seasonality data (von den Driesch and Wodtke 1997). As at WJ13 restricting the hunting season to a less busy time of year, away from crop planting and lambing, provides a credible explanation and is explored further below in section 8.1.

\subsection{Natufian and early PPNA}

A brief summary of the preliminary Natufian and early PPNA results are presented here, although sample numbers are small and do not reach the threshold for analytical confidence. Consequently, no attempt is made to interpret the findings, which are puzzling and demand future exploration.

Shubayqa 1 and Shubayqa 6 are $0.7 \mathrm{~km}$ apart and overlook a large qa within the Wadi Rajil, which drains through the basalt from the Jebel Druze to the Azraq Oasis. SH1 is a Natufian site with two separate phases of occupation between 14.4-13.1 ka cal BP, and a brief occupation at $12.0 \mathrm{ka} \mathrm{cal} \mathrm{BP,} \mathrm{whilst} \mathrm{SH6} \mathrm{is} \mathrm{a} \mathrm{late} \mathrm{Natufian}$ and PPNA site with dates between 12.0-10.6 ka cal BP. These dates indicate intermittent occupation through the Bolling-Allerod, stages of the Younger Dryas and early Holocene (Richter 2017; Richter et al. 2017). The carbonate isotopic data resemble those of the Early Epipalaeolithic with closely grouped, very seasonal signatures of animals all born in the spring, but with a slightly greater emphasis on arid-adapted or stressed vegetation. The flat strontium isotope signature shows herds remained in one geological area throughout the year, but surprisingly, values more closely match our baseline signature for the south-west basalt fringes rather than deep within the basalt near the sites. Body-part evidence at SH1 points to whole carcasses being brought onto site, which does not sit easily with herds living a minimum of 45-50 km further south on the Tertiary limestone/Quaternary gravels. However, it should be noted that wadis cut through the basalts towards the underlying limestones in some areas, so it is possible that this isotopic signature could be obtained from gazelle grazing/browsing along wadi courses closer to the sites, although Henton et al. (2018) found no evidence of this in their baseline work. Turning to hunting seasonality, DMA suggests Shubayqa gazelle were hunted in seasons when browse predominated (late summer through to winter), but more commonly when grasses flourished in spring, as at earlier Epipalaeolithic sites. This does not fully match zooarchaeological seasonality evidence at SH1 and, to a lesser extent, at SH6, where autumn/winter is identified as the main hunting season, reserving spring for rich water-fowl resources, but the small sample size precludes further interpretation.

\section{Discussion}

Results produced by this research fall comfortably within the expected ranges established in previous research (see section 4.1), provide isotopic and dental microwear signatures relevant to the Badia's seasons and locations, and are thus suitable for testing the four hypothesized gazelle mobility patterns outlined in section 2.3 above. Where we have compared datasets, results have been tested for significance, although we note small sample sizes for some sites, and further analyses on additional specimens would certainly strengthen interpretations. Despite large faunal assemblages from prehistoric sites in the Badia (see Martin et al. 2016), intact gazelle teeth at the age-stages required for this kind of isotopic analyses were not numerous and often poorly preserved, thus limiting suitable samples. In particular, an enhanced dataset is necessary before attempting interpretation of gazelle behaviour in the Natufian/PPNA. 
While the aim of this paper was to broadly compare Early Epipalaeolithic gazelle mobility with that in the Neolithic of the Badia, future work would benefit greatly from chronological fine-tuning, especially of the Neolithic patterns, where larger samples may allow chronological breakdown of PPNB and Late Neolithic phases, key to exploring the impact of pastoralism on gazelle herds. Parallel research could also usefully attempt isotopic and DMA signatures for domestic caprines in the early Holocene of the Badia to explore their mobility and therefore herding patterns (e.g. Miller 2012), and to make comparisons with the gazelle data.

With the above limitations in mind, we argue that:

a. Models of longer-distance seasonal gazelle herd migrations are not supported by the results presented in this research; likewise, there is no evidence for seasonal transhumant patterns of gazelle mobility. Of the gazelle mobility patterns presented in section 2.3 above, models 2, 3 and 4 find no support in the evidence. Rather, in the localities and timeframes examined for the Epipalaeolithic and Neolithic, herds appear to have adapted to well-resourced environments, remaining in a relatively localized area in discrete groupings throughout the year, thus leaning towards our hypothesized mobility pattern 1.

b. Consequently, we argue that gazelle herds could have provided year-round resources for hunters in the Badia since their presence does not appear restricted to certain seasons. While herds may well have seasonally varied in density, groupings and body condition (e.g. Baharav 1974; 1983; Martin 2000: table 10), their local mobility patterns had the potential to support multi-seasonal or longer-term seasonal occupation.

c. Interesting differences in gazelle herd location have been revealed between the Early Epipalaeolithic and Early Holocene/Neolithic. In the Early Epipalaeolithic herds appear to have broadly shared landscape locations with humans, having the same isotopic signatures as those expected in the vicinity of the archaeological sites where they were retrieved. In other words, Early Epipalaeolithic hunter-gatherer occupations did not significantly impact the ranges of gazelle herds, confirming zooarchaeological results (Martin et al. 2016). By the early Holocene, however, gazelle herds seem to have shifted to locations further afield from Neolithic settlements, although not distant, a pattern expanded on below.

d. In addition to herd location, gazelle foraging patterns remained stable during the Early Epipalaeolithic, becoming more varied in the Early Holocene, consistent with behavioural adjustments to manage increasing resource patchiness (e.g. Cunningham and Wacher 2009). Resource pressure is unlikely to have resulted from environmental factors alone in this period, given that the Middle and Late PPNB and earliest Late Neolithic seems relatively moist in the southern Levant (see section 2.2). A more convincing explanation for habitat loss in the Neolithic may be the well-attested expansion of pastoralism into the Badia (Garrard et al. 1996; Rollefson et al. 2014).

e. Isotopic results show that most gazelle were born in one season, almost certainly spring. This fits expectations of a steppic/desert species inhabiting a strongly seasonal environment where resources limit a second annual calving period (e.g. Baharav 1974). We note that DMA and fusion data show many of the Badia study sites to have at least some gazelle spring deaths, which further eliminates the Abu Hureyra long-distance migration model (our Pattern 3 above) which sees G. subgutturosa birthing in the Euphrates region in the spring (Legge and Rowley-Conwy 2000). That both the Jordanian Badia and the Middle 
Euphrates, at least $600 \mathrm{~km}$ away, witness gazelle presence in spring, further confirms the isotopic evidence presented here, that these different Levantine regions sustained distinct gazelle populations.

f. There is a clear chronological shift in dominant hunting season from the grass-rich late winter/spring during the Early Epipalaeolithic, to browse-rich late summer/autumn in the Early Holocene. While there is evidence for some hunting in other seasons at all Badia sites, hunting was restricted solely to summer/autumn in the Highland 'Ain Ghazal site, where arable and domestic herding tasks had taken priority over-hunting, fitting the seasonal scheduling model proposed for that site (Rollefson and KöhlerRollefson 1993).

\subsection{Hunting practices}

How does the evidence for gazelle seasonal mobility contribute to interpretations of hunting practices in the Badia, and at the case-study sites? The predictable year-round presence of gazelle herds in presumably high densities clearly underpinned the Early Epipalaeolithic 'megasites' of Kharaneh IV and Wadi Jilat 6 in the limestone steppe, since gazelle make up over $70 \%$ of these assemblages. While interpreted as hunter-gatherer aggregation sites, Maher et al. (2012a) also argue that for Kharaneh IV at least, there was multi-seasonal occupation covering extended parts of the year, and the current study (and Henton et al. 2017) demonstrates how herds could have sustained multi-season hunting in the vicinity, although winter/spring does appear the dominant hunting season. We show elsewhere (Martin et al. 2010) that there is no evidence for mass gazelle culls at Kharaneh IV or Wadi Jilat 6, and no sign of hunting pressure. The lack of seasonal large-scale gazelle movements or migrations in the Badia, demonstrated in the results presented in this paper (see also Henton et al. 2017) might explain why herd intercept and mass culling techniques were not practiced in the Early Epipalaeolithic in the Badia (cf. Driver 1990). Hunters at Ayn Qasiyya, at Azraq Oasis, similarly had access to relatively local gazelle herds year-round. We assume that the basalt steppe to the north and east was also populated with fairly abundant herds: unfortunately the absence of Early Epipalaeolithic sites provides no view into wildlife or hunting there in this period. The lack of occupation is puzzling and is difficult to attribute to adverse environmental or resource conditions, since it seems likely that wildlife should have thrived in this area, as it did in later periods. It is possible that with potentially lower human population levels in the Early Epipalaeolithic, groups were less attracted to the rocky basalt hammada, where flint/chert as a raw material was also absent, but the overall reasons remain unclear.

The Late PPNB was likely to have seen the first livestock pastoralists in the Badia (Rollefson et al. 2014) and while the scale of initial caprine herding is difficult to detect, we find an increase in settled occupations and built structures, for example at Azraq 31 and Bawwab al-Ghazal at the Azraq Oasis, with the suggestion of herding close to sites (Quintero et al. 2004; Rollefson et al. 1999). The isotopic and DMA results presented above show gazelle ranges to have shifted from the oasis into the steppe, and hunting seems to take place primarily in the arid summer-season, which we interpret as resulting from herding activities beginning to displace gazelle herds and constrain hunting seasonality.

By contrast, LPPNB Dhuweila shows no evidence for caprine herding, but seems located for dedicated and specialized gazelle capture (Betts 1998; Martin 1998). We have shown elsewhere (Martin et al. 2016) that the 
gazelle assemblage from Dhuweila is the earliest in the Badia to show sure signs of hunting pressure, with unsustainably high (55\%) juvenile culls and indiscriminate targeting of infant age cohorts. The isotope and DMA results contribute to this picture by demonstrating multi-seasonal hunting activity, and revealingly, signs that gazelle herds were driven towards Dhuweila from further afield. This combined evidence provides strong support for the idea of gazelle herd driving, most likely into traps nearer the site, with the use of guide-walls, consistent with Alison Betts' long-held views on the antiquity of landscape features at Dhuweila (Betts 1998; 2014 and references therein).

Dhuweila also shows how abundant gazelle herds were in the LPPNB and Late Neolithic eastern Badia area (making up $>90 \%$ of the assemblage in each period (Martin 1998)), while coeval occupations in the western limestone Badia areas and around the Azraq oasis saw far lower proportions, for example 20\% at Late Neolithic Wadi Jilat 13. An obvious explanation is that the occupants at Wadi Jilat 13 were primarily caprine herders who hunted opportunistically (Martin 1999). But the results presented in this paper add two key insights; first that gazelle territories were distant from the site, most likely displaced by livestock herds, and second, that gazelle hunting took place in multiple seasons, adding not only spatial but extended seasonal pressure to the wildlife displacement. The overall picture gained is that by the Late Neolithic, the landscape in many areas of the Badia was increasingly impacted by pastoralism. This gives support to the argument of Rollefson et al. (2014) that the Late Neolithic saw pastoralism appear in the Badia on a far more significant scale than had previously been envisaged by scholars.

Gazelle hunting was clearly not of great importance at PPNB/LN 'Ain Ghazal in the Jordan Highlands, where domestic caprines dominate faunal assemblages from the MPPNB onwards (von den Dreisch and Wodtke 1997; Wasse 1997). The site, however, provides a clear example of how more permanent large-scale occupation, with mixed farming and a dominant pastoral component can displace wildlife, particularly for gazelle species who are known to have long flight distances. For G. gazella for example, Mendelssohn (1974) describes herds taking flight for up to $1 \mathrm{~km}$ when startled by predators and humans, with hunting pressure increasing this distance. He also describes gazelle reacting to humans and objects moving at distances of $1 \mathrm{~km}$ away. Isotope results show the gazelle hunted and transported to 'Ain Ghazal to have stable territories some distance east of the site, which could indicate either hunting forays away from the settlement, or that they were hunted by caprine herders attached to the site, who, as Köhler-Rollefson $(1988 ; 1992)$ and Rollefson (2011) have proposed, became seasonally transhumant by the Pre-Pottery Neolithic C (PPNC) or Late Neolithic, spending spring/summers in the Badia, returning after the harvest in the autumn. Support is given to this latter idea by the DMA seasonality data, showing summer/autumn gazelle hunts at 'Ain Ghazal. A future study of isotope and DMA signatures in the 'Ain Ghazal caprine remains could provide useful comparative datasets with which to test this proposition.

\subsection{Desert kites}

The emerging picture, of gazelle herd range fragmentation by pastoralism in the moister areas of the Badia along with the displacement of large gazelle herds to the deeper eastern and southern Badia by at least the Late Neolithic and perhaps the Late PPNB, has implications for ongoing discussion about the dating and functioning of the desert kite hunting structures. While debate continues as to the chronology of kite construction (Bar-Oz et 
al. 2011; Betts 2014; Morandi Bonacossi 2014; Zeder et al. 2013), there is firm evidence of PPNB kite construction in southern Jordan (Abu-Azizeh and Tarawneh 2015) and a strong likelihood that some kites in the Badia date to the Neolithic (Betts and Burke 2015; Kempe and Al-Malabeh 2013). If this is the case, they appear to be a response to an increasingly pastoral landscape, in which caprine herders are primarily focused on keeping flocks alive for their products. Vigne and Helmer (2007) have argued that dairying was in place from the start of PPNB caprine domestication, and whether this is the case or not, it is highly likely that dairying was practiced by the time Late Neolithic herders moved out into the eastern Badia in large numbers (Rollefson et al. 2014). If caprines were primarily kept 'on the hoof', gazelle become a good source of meat. Kites act not only as effective hunting traps but could also serve to partition the landscape into pasturing zones and game reservoirs in wildlife areas. The increased aridity of the Late Neolithic after $c .8 .6 \mathrm{ka}$ cal BP (see section 2.2) combined with pastoral competition for graze, may have pushed gazelle herds into seasonal movements in and out of the Badia on a south-east/north-west axis, in periods later than those we have samples from, which would fit the predominant pattern of kites which have open arms towards the east and south (Betts and Burke 2015). This is a form of gazelle seasonal mobility that was not one of our initial four for testing since it would be difficult to detect isotopically; it would, however, be a fruitful avenue for future research if appropriate samples become available from the Late Neolithic and Bronze Ages onwards.

\section{Conclusion}

This study demonstrates the powerful combination of dental isotope analysis alongside dental microwear analysis to elucidate gazelle seasonal mobility in the Jordanian Badia in prehistory. While sample sizes for analyses are sometimes small, results suggest large-scale shifts in gazelle habitats in the Badia between the Early Epipalaeolithic and PPNB/Late Neolithic which we attribute more to the effects of encroaching pastoralists and their flocks than to shifts in environments, which arid-adapted gazelle herds should be able to withstand (e.g. Cunningham and Wacher 2009). Future studies on larger samples from the Late Epipalaeolithic can potentially add understanding of how wildlife responded to later Pleistocene environmental and cultural conditions, and the Younger Dryas in particular.

For the Early Epipalaeolithic in the Badia, results presented here challenge the received wisdom of large-scale migrating gazelle herds being the foundation of the steppic 'megasites' (e.g. Goring-Morris 1995). We find instead a picture of abundant year-round resources, which raises the possibility that settlements could be sustained, and endure, over much longer seasons (Maher et al. 2012a). As such, this study is an example of a wider vein of research aimed at producing evidence for prehistoric wildlife behaviour (e.g. Burke 2002; Julien et al. 2012) rather than assuming that more recent historical observations hold for the distant past. Standard zooarchaeology is useful but limited in this respect since it necessarily interprets animal 'deadstock', rather than more nuanced information about location and seasonality of animals during life (ie 'livestock') as provided by isotopic analysis.

Reconstruction of wildlife seasonal mobility is, of course, challenging, and as this study demonstrates, can only provide small 'windows' into undoubtedly complex and dynamic faunal distributions and movements. So, while this study finds gazelle range-fragmentation in the Neolithic and, most probably, onwards, resulting from the 
pressures of livestock herding in the Badia, it is worth bearing in mind that the resilient gazelle remained relatively abundant in the region despite millennia of pastoralist activity until the mid-20th century, when firearms all but wiped them out locally (Nelson 1973).

\section{Acknowledgements}

This work was supported by The Leverhulme Trust under grant RPG-2013-223. We are grateful to the Department of Antiquities, Jordan, and to the British Institute in Amman, CBRL, for their support in Jordan. We thank Alison Betts, Lisa Maher, Tobias Richter and Gary Rollefson for permission to study materials. Many thanks also to Lisa Yeomans, Sandra Bond and Tom Gregory for research support.

\section{References}

Abu-Azizeh, W. and Tarawneh, M. B. 2015. Out of the harra: desert kites in south-eastern Jordan. New results from the South Eastern Badia Archaeological Project. Arabian Archaeology and Epigraphy 26: 95-119.

Adams, R. 1977. Saudi Arabian archaeological reconnaissance 1976. Atlal 1: 21-40.

Ames, C. and Cordova, C. 2015. Middle and Late Pleistocene landscape evolution at the Druze marsh site in northeast Jordan. Geoarchaeology 30: 307-29.

Baharav, D. 1974. Notes on the population structure and biomass of the mountain gazelle, Gazella gazella gazella. Israel Journal of Zoology 23: 39-44.

Baharav, D. 1981. Food habits of the mountain gazelles in semi-arid habitats of eastern Lower Galilee. Journal of Arid Environments 4: 63-69.

Baharav, D. 1983. Observation on the ecology of the mountain gazelle in the Upper Galilee, Israel. Mammalia 47: 59-69.

Baird, D. 1994. Chipped stone production technology from the Azraq Project Neolithic sites. In, Gebel, H-G. and Kozlowski, S. K. (eds), Neolithic Chipped Stone Industries of the Fertile Crescent: 525-41. Studies in Near Eastern Production, Subsistence and Environment 1. Berlin: ex oriente.

Balasse, M. 2002. Reconstructing dietary and environmental history from enamel isotopic analysis: time resolution of intra-tooth sequential sampling. International Journal of Osteoarchaeology 12: 155-65.

Balasse, M., Ambrose, S., Smith, A. and Price, D. 2002. The seasonal mobility model for prehistoric herders in the south-west Cape of South Africa assessed by isotopic analysis of sheep tooth enamel. Journal of Archaeological Science 29: 917-32. 
Bar-Oz, G., Zeder, M. and Hole, F. 2011. Role of mass-kill hunting strategies in the extirpation of Persian gazelles (Gazella subgutturosa) in the northern Levant. Proceedings of the National Academy of Science 108: $7345-50$.

Barge, O., Brochier, J. E., Chahoud, J., Chataigner, C., Chambrade, M.-L., Karakhanyan, A., Régagnon, E. and Crassard, R. 2013. Towards a new approach to the 'kites phenomenon' in the Old World: the GLOBALKITES Project. Antiquity 87 (338) Project Gallery. http://antiquity.ac.uk/projgall/barge338/

Batanouny, K. 2001. Plants in the Deserts of the Middle East. Berlin: Springer.

Bender, F. 1974. Geology of Jordan. Berlin: Borntraeger.

Bender, M. 1971. Variations in the ${ }^{13} \mathrm{C} /{ }^{12} \mathrm{C}$ ratios of plants in relation to the pathways of photosynthetic carbon dioxide fixation. Phytochemistry 10: 1239-45.

Bentley, A. 2006. Strontium isotopes from the earth to the archaeological skeleton: a review. Journal of Archaeological Method and Theory 13: 135-87.

Betts, A. 1985. Black Desert survey, Jordan: preliminary report. Levant 17: 29-52.

Betts, A. (ed.) 1998. The Harra and the Hamad: Excavations and Explorations in Eastern Jordan. Sheffield: Sheffield Academic Press.

Betts, A. 2014. A response to Zeder, Bar-Oz, Rufolo and Hole (2013). Quaternary International 338: $125-27$.

Betts, A. and Burke, D. 2015. Desert kites in Jordan - a new appraisal. Arabian Archaeology and Epigraphy 26: 74-94.

Betts, A., Cropper, D., Martin, L. and McCartney, C. (eds) 2013. The Later Prehistory of the Badia: Excavations and Surveys in Eastern Jordan, Volume 2. Oxford: Oxbow.

Bogaard, A., Henton, E., Evans, J., Twiss, K., Charles, M., Vaiglova, P. and Russell, N. 2014. Locating land use at Neolithic Çatalhöyük, Turkey: the implications of ${ }^{87} \mathrm{Sr} /{ }^{86} \mathrm{Sr}$ signatures in plants and sheep tooth sequences. Archaeometry 56: 860-77.

Breeze, P., Groucutt, H., Drake, N., White, T., Jennings, R. and Petraglia, M. 2016. Palaeohydrological corridors for hominin dispersals in the Middle East 250-70,000 years ago. Quaternary Science Reviews 144: $155-85$.

Britton, K., Grimes, V., Dau, J. and Richards, M. 2009. Reconstructing faunal migrations using intra-tooth 
sampling and strontium and oxygen isotope analyses: a case study of modern caribou. (Rangifer tarandus granti). Journal of Archaeological Science 36: 1163-72.

Bryant, J. and Froelich, P. 1995. A model of oxygen isotope fractionation in body water of large mammals. Geochimica et Cosmochimica Acta 59: 4523-37.

Burke, A. 2002. Palaeoethology as an archaeological tool: a model for the social and spatial behaviour of Equus hydruntinus. In, Mashkour, M. (ed.), Equids in Time and Space (Proceedings of the 9th ICAZ Conference), Durham: 62-69. Oxford: Oxbow Books.

Byrd, B. 1992. The dispersal of food production across the Levant. In, Price, T. D. (ed.), Transitions to Agriculture in Prehistory: 49-61. Madison: Prehistory Press.

Byrd, B. and Garrard, A. 1990. The last Glacial Maximum in the Jordanian desert. In, Gamble, C. and Soffer, O. (eds), The World at 18,000 BP. Volume 2. Low Latitudes: 78-96. London: Unwin Hyman.

Byrd, B. and Garrard, A. 2013. Section C: the Late Palaeolithic — chipped stone assemblages. In, Garrard, A. and Byrd, B. (eds), Beyond the Fertile Crescent: Late Palaeolithic and Neolithic Communities of the Jordanian Steppe. The Azraq Basin Project, Volume 1: 137-93. Oxford: Oxbow.

Byrd, B., Garrard, A. and Brandy, P. 2016. Modelling foraging ranges and spatial organization of Late Pleistocene hunter-gatherers in the southern Levant — a least-cost GIS approach. Quaternary International 396: $62-78$.

Cerling, T. and Harris J. 1999. Carbon isotope fractionation between diet and bioapatite in ungulate mammals and implications for ecological and paleoecological studies. Oecologia 120: 347-63.

Colledge, S. 2001. Plant Exploitation on Epipalaeolithic and Early Neolithic Sites in the Levant. Oxford: British Archaeological Reports S986.

Cropper, D. 2011. Lithic Technology and Regional Variation in Late Neolithic Jordan. Oxford: British Archaeological Reports S2291.

Cunningham, P. L. and Wacher, T. 2009. Changes in the distribution, abundance and status of Arabian sand gazelle (Gazella subgutturosa marica) in Saudi Arabia: a review. Mammalia 73: 203-10.

Cunningham, P. and Wronski, T. 2011. Seasonal changes in group size and composition of Arabian sand gazelles Gazella subgutturosa marica during a period of drought in central western Saudi Arabia. Current Zoology 57: 36-42. 
Dansgaard, W. 1964. Stable isotopes in precipitation. Tellus 16: 436-68.

De Niro, M. and Epstein, S. 1978. Influence of diet on the distribution of carbon isotopes in animals. Geochimica et Cosmochimica Acta 42: 495-506.

Derevyagin, P. Y. 1947. On the seasonal migrations of the dzeiran from the region to the south of Lake Balkhash into the Kalkan-Matai/Myn-Bulak Mountain Valley. Bulletin Academy Sciences Kazakh SSR 4: 33 38. [In Russian.]

Driver, J. C. 1990. Meat in due season: the timing of communal hunts. In, Davis, L. B. and Reeves, B. O. K. (eds), Hunters of the Recent Past: 11-33. London: Unwin Hyman.

Ehleringer, J., Cerling, T. and Helliker, B. 1997. $\mathrm{C}_{4}$ photosynthesis, atmospheric $\mathrm{CO}_{2}$, and climate. Oecologia 112: 285-99.

Enzel, Y., Amit, R., Dayan, U., Crouvi, O., Kahana, R., Ziv, B. and Sharon, D. 2008. The climatic and physiographic controls of the eastern Mediterranean over the late Pleistocene climates in the southern Levant and its neighbouring deserts. Global and Planetary Change 60: 165-92.

Faure, G. and Powell, J. 1972. Strontium Isotope Geology. New York: Springer.

Fricke, H. and O’Neil, J. 1996. Inter- and intra-tooth variations in the oxygen isotope composition of mammalian tooth enamel phosphate. Palaeogeography, Palaeoclimatology, Palaeoecology 126: 91-99.

Garrard, A. 1998. Environmental and cultural adaptations in the Azraq Basin: 24,000-7,000 BP. In, Henry, D. (ed.), The Prehistoric Archaeology of Jordan: 139-48. Oxford: British Archaeological Reports S705.

Garrard, A., Baird, D., Colledge, S., Martin, L. and Wright, K. 1994. Prehistoric environment and settlement in the Azraq Basin: an interim report on the 1987 and 1988 excavation seasons. Levant 26:73-109.

Garrard, A. and Byrd, B. 1992. New dimensions to the Epipalaeolithic of the Wadi-el-Jilat in Central Jordan. Paléorient 18(1): 47-62.

Garrard, A. and Byrd, B. 2013. Beyond the Fertile Crescent: Late Palaeolithic and Neolithic Communities of the Jordanian Steppe. The Azraq Basin Project, Volume 1. Oxford: Oxbow.

Garrard, A., Colledge, S., Martin, L. 1996. The emergence of crop cultivation and caprine herding in the 'marginal zone' of the southern Levant. In, Harris, D. (ed.), The Origins and Spread of Agriculture and Pastoralism in Eurasia: 204-26. London: University College London. 
Goodfriend, G. A. 1991. Holocene trends in ${ }^{18} \mathrm{O}$ in land snail shells from the Negev Desert and their implications for changes in rainfall source areas. Quaternary Research 35: 417-26.

Goring-Morris, N. 1995. Complex hunter-gatherers at the end of the Palaeolithic (20,000-10,000 BP). In, Levy, T. (ed.), The Archaeology of Society in the Holy Land: 142-67. Leicester: Leicester University Press.

Graustein, W. 1989. ${ }^{87} \mathrm{Sr} /{ }^{86} \mathrm{Sr}$ ratios measure the sources and flow of strontium in terrestrial ecosystems. In, Rundel, P., Ehleringer, J. and Nagy, K. (eds), Stable Isotopes in Ecological Research: 491-512. New York: Springer-Verlag.

Henry, D. 1995. Prehistoric Cultural Ecology and Evolution: Insights from Southern Jordan. New York: Plenum Press.

Henton, E. 2012. The combined use of oxygen isotopes and microwear in sheep teeth to elucidate seasonal management of domestic herds: the case study of Çatalhöyük, central Anatolia. Journal of Archaeological Science 30: 3264-76.

Henton, E., Martin, L., Garrard, A., Jourdan, A-L., Thirlwall, M. and Boles, O. 2017. Gazelles seasonal mobility in the Jordanian steppe: the use of dental isotopes and microwear as environmental markers, applied to Epipalaeolithic Kharaneh IV. Journal of Archaeological Science: Reports 11: 147-58.

Henton, E., Ruben, I., Palmer, C., Martin, L., Garrard, A., Thirlwall, M. and Jourdan A-L. 2018. The seasonal mobility of prehistoric gazelle herds in the Azraq Basin, Jordan: modelling alternative strategies using stable isotopes. Environmental Archaeology 23: 187-99.

Heptner, V., Nasimovich, A. and Bannikov, A. 1988. Mammals of the Soviet Union. Volume 1. Artiodactyla and Perissodactyla. Washington: Smithsonian Institute.

Hillman, G. 1996. Late Pleistocene changes in wild plant-foods available to hunter-gatherers of the northern Fertile Crescent: possible preludes to cereal cultivation. In, Harris, D. R. (ed.), The Origins and Spread of Agriculture and Pastoralism: 159-203. London: University College London.

Hoppe, K., Koch, P., Carlson, R. and Webb, D. 1999. Tracking mammoths and mastodons: reconstruction of migratory behavior using strontium isotope ratios. Geology 27: 439-42.

Jones, M., Maher, L., Macdonald, D., Ryan, C., Rambeau, C., Black, S. and Richter, T. 2016. The environmental setting of Epipalaeolithic aggregation site Kharaneh IV. Quaternary International 396: 95-104.

Jones, M. and Richter, T. 2011. Paleoclimatic and archaeological implications of Pleistocene and Holocene environments in Azraq, Jordan. Quaternary Research 76: 363-72. 
Julien, M.-A., Bocherens, H., Burke, A., Drucker, D., Patou-Mathis, M., Krotova, O. and Pe'an S. 2012. Were European steppe bison migratory? ${ }^{18} \mathrm{O},{ }^{13} \mathrm{C}$ and $\mathrm{Sr}$ intra-tooth isotopic variations applied to a palaeoethological reconstruction. Quaternary International 271: 106-19.

Kempe, S. and Al-Malabeh, A. 2013. Desert kites in Jordan and Saudi Arabia: structure, statistics and function, a Google Earth study. Quaternary International 297: 126-46.

Köhler-Rollefson, I. 1988. The aftermath of the Levantine Neolithic revolution in the light of ecological and ethnographic evidence. Paléorient 14(1): 87-93.

Köhler-Rollefson, I. 1992. A model for the development of nomadic pastoralism on the Transjordanian plateau. In, Bar-Yosef, O. and Khazanov, A. (eds), Pastoralism in the Levant. Archaeological Materials in Anthropological Perspectives: 11-18. Madison: Prehistory Press.

Kohn, M., Schoeninger, M. and Valley, J. 1998. Variability in oxygen isotope compositions of herbivore teeth: reflections of seasonality or developmental physiology? Chemical Geology 152: 97-112.

Lancaster, W. and Lancaster, F. 1991. Limitations on sheep and goat herding in the eastern Badia of Jordan: an ethno-archaeological enquiry. Levant 23: 125-13.

Legge, A. and Rowley-Conwy, P. 1987. Gazelle killing in Stone-age Syria. Scientific American 255: 88-95.

Legge, A. and Rowley-Conwy, P. 2000. The exploitation of animals. In, Moore, A., Hillman, G. and Legge, A., Village on the Euphrates: from Foraging to Farming at Abu Hureyra: 455-71. Oxford: Oxford University Press.

Leimgruber, P., McShea, W. J., Brookes, C. J., Bolor-Erdene, L., Wemmer, C. and Larson, C. 2001. Spatial patterns in relative primary productivity and gazelle migration in the Eastern Steppes of Mongolia. Biological Conservation 102: 205-12.

Maher, L., MacDonald, D., Allentuck, A., Martin, L., Spyrou, A. and Jones, M. 2016. Occupying wide open spaces? Late Pleistocene hunter-gatherer activities in the Eastern Levant. Quaternary International 396: 79-94.

Maher, L., Richter, T., Macdonald, D., Martin, L. and Stock, J. 2012a. Twenty thousand-year-old huts at a hunter-gatherer settlement in eastern Jordan. PLoS ONE 7, e31447. doi:10.1371/journal.pone.0031447.

Maher, L., Richter, T. and Stock, J. 2012b. The Pre-Natufian Epipalaeolithic: long-term behavioral trends in the Levant. Evolutionary Anthropology 21: 69-81. 
Mainland, I. 1998. The lamb's last supper: the role of dental microwear analysis in reconstruction of livestock diet in the past. Environmental Archaeology 1: 55-62.

Martin, L. 1998. The animal bones. In, Betts, A. V. (ed.), The Harra and the Hamad: Excavations and Exploration in Eastern Jordan, Volume 1: 159-84. Sheffield Archaeological Monographs 9. Sheffield: Sheffield Academic Press.

Martin, L. 1999. Mammal remains from the eastern Jordanian Neolithic, and the nature of caprine herding in the steppe. Paléorient 25(2): 87-104.

Martin L. 2000. Gazelles (Gazella spp.) behavioural ecology: predicting animal behaviour for prehistoric environments in south-west Asia. Journal of Zoology, London 250: 13-30.

Martin, L., Edwards, Y. and Garrard, A. 2010. Hunting practices at an Eastern Jordanian Epipalaeolithic aggregation site: the case of Kharaneh IV. Levant 42: 107-35.

Martin, L., Edwards, Y., Roe, J. and Garrard, A. 2016. Faunal turnover in the Azraq Basin, eastern Jordan 28,000 to 9,000 cal BP, signalling climate change and human impact. Quaternary Research 86: 200-19.

Mendelssohn, H. 1974. The development of the populations of gazelles in Israel and their behavioural adaptations. In, Geist, V. and Walther, F. (eds), The Behaviour of Ungulates and its Relation to Management. Volume 2: 722-43. Morges: International Union for Conservation of Nature and Natural Resources.

Merceron, G., Schulz, E., Kordos, L. and Kaiser, T. 2007. Paleoenvironment of Dryopithecus brancoi at Rudabánya, Hungary: evidence from dental meso- and micro-wear analyses of large vegetarian mammals. Journal of Human Evolution 53: 331-49.

Migowski, C., Stein, M., Prasad, S., Negendank, J. F. W. and Agnon, A. 2006. Holocene climatic variability and cultural evolution in the Near East from the Dead Sea sedimentary record. Quaternary Research 66: 421-31.

Miller, H. 2012. The origins of nomadic pastoralism in the southern Levant: stable isotope, chipped stone and architectural analysis of archaeological evidence. PhD. University of Liverpool.

Montgomery, J., Evans, J. and Horstwood, M. 2010. Evidence for long-term averaging of strontium in bovine enamel using TIMS and LA-MC-ICP-MS strontium isotope intra-molar profiles. Environmental Archaeology 15: $32-42$.

Moore, A., Hillman, G. and Legge, A. 2000. Village on the Euphrates: from Foraging to Farming at Abu Hureyra. New York: Oxford University Press. 
Morandi Bonacossi, D. 2014. Desert-kites in an aridifying environment. Specialised hunter communities in the Palmyra steppe during the middle and late Holocene. In, Morand Bonacossi, D. (ed.), Settlement Dynamics and the Human-Landscape Interaction in the Dry Steppes of Syria: 33-47. Studia Chaburensia 4. Weisbaden: Harrassowitz.

Munro, N., Bar-Oz, G. and Stutz, A. 2009. Aging mountain gazelles (Gazella gazelles): refining methods of tooth eruption and wear and bone fusion. Journal of Archaeological Science 36: 752-63.

Murtskhvaladze, M., Gurielidze, Z., Kopaliani, N. and Tarkhnishvili, D. 2012. Gene introgression between Gazella subguturrosa and G. marica: limitations of maternal inheritance analysis for species identification with conservation purposes. Acta Theriologica 57: 383.

Nelson, B. 1973. Azraq: Desert Oasis. London: Allen Lane.

O'Regan, B. P. 1980. Ecology and conservation of the jebeer gazelle and wild ass in the Dasht E Kavir, Iran. MSc. University of London.

Pearson, J. and Grove, M. 2013. Counting sheep: sample size and statistical inference in stable isotope analysis and palaeodietary reconstruction. World Archaeology 45: 373-87.

Quintero, L. A., Rollefson, G. O. and Wilke, P. J. 2004. Highland towns and desert settlements: origins of nomadic pastoralism in the Jordanian Neolithic. In, Bienert, H-D., Gebel, H-G. and Neef, R. (eds), Central Settlements in Neolithic Jordan: 201-13. Studies in Early Near Eastern Production, Subsistence and Environment 5. Berlin: ex oriente.

Ramsey, M., Jones, M., Richter, T. and Rosen, A. 2015. Modifying the marsh: evaluating Early Epipaleolithic hunter-gatherer impacts in the Azraq wetland, Jordan. The Holocene 25: 1553-64.

R Core Team. 2018. R: A Language and Environment for Statistical Computing. Vienna: R Foundation for Statistical Computing.

Richter, T. 2017. The Late Epipalaeolithic and Early Neolithic in the Jordanian Badia: recent fieldwork around the Qa' Shubayqa. Near Eastern Archaeology 80: 94-101.

Richter, T., Arranz-Otaegui, A., Yeomans, L. and Boaretto, E. 2017. High resolution AMS dates from Shubayqa 1, northeast Jordan reveal complex origins of Late Epipalaeolithic Natufian in the Levant. Scientific Reports 7. doi:10.1038/s41598-017-17096-5 
Richter, T. and Maher, L. 2013a. Terminology, process and change; reflections on the Epipalaeolithic of Southwest Asia. Levant 45: 121-32.

Richter, T., Maher, L., Garrard, A., Edinborough, K., Jones, M. and Stock, J. 2013. Epipalaeolithic settlement dynamics in southwest Asia: new radiocarbon evidence from the Azraq Basin. Journal of Quaternary Science 28: 467-79.

Richter, T., Stock, J., Maher, L. and Hebron, C. 2010. An Early Epipalaeolithic sitting burial from the Azraq Oasis, Jordan. Antiquity 84: 321-34.

Rivals, F., Solounias, N. and Schaller, G. 2011. Diet of Mongolian gazelles and Tibetan antelopes from steppe habitats using premaxillary shape, tooth mesowear and microwear analyses. Mammalian Biology 76: 358-64.

Robinson, S. A., Black, S., Sellwood, B. W. and Valdes, P. J. 2006. A review of palaeoclimates and palaeoenvironments in the Levant and Eastern Mediterranean from 25,000 to 5,000 years BP: setting the environmental background for the evolution of human civilisation. Quaternary Science Reviews 25: 1517-41.

Rollefson, G. O. 2011. The greening of the Badlands: pastoral nomads and the 'conclusion' of Neolithization in the southern Levant. Paléorient 37(1): 101-09.

Rollefson, G. O. 2015. ‘Ain Ghazal, Jordan. In, Barker, G. and Goucher, C. (eds), Cambridge World History. Volume 2: A World with Agriculture 12,000 BCE to 500 CE: 243-60. Cambridge: Cambridge University Press.

Rollefson, G. O. and Köhler-Rollefson, I. 1993. PPNC adaptations in the first half of the $6^{\text {th }}$ millennium BC. Paléorient 19(1): 33-42.

Rollefson, G., Quintero, L. and Wilke, P. 1999. Bawwab al-Ghazal: preliminary report on the 1998 testing season. Neo-lithics 1(99): 2-4.

Rollefson, G., Rowan Y. and Wasse, A. 2014. The Late Neolithic colonization of the Eastern Badia of Jordan. Levant 46: 285-301.

Rossignol-Strick, M. 1995. Sea-land correlation of pollen records in the eastern Mediterranean for the glacialinterglacial transition: biostratigraphy versus radiometric time-scale. Quaternary Science Reviews 14: 893-915.

Rossignol-Strick, M. 1999. The Holocene climatic optimum and pollen records of sapropel 1 in the eastern Mediterranean, 9000-6000 BP. Quaternary Science Reviews 18: 515-30.

Rowan, Y. M., Rollefson, G., Wasse, A., Hill, A. C. and Kersel, M. M. 2017. The Late Neolithic presence in the Black Desert. Near Eastern Archaeology 80: 102-13. 
Rozanski, K., Araguas-Araguas, L. and Gonfiantini, R. 1993. Isotopic patterns in modern global precipitation. Climate change in continental isotopic records. American Geophysics Union, Geophysics Monograph 78: 1-36.

Sillen, A., Hall, G., Richardson, S. and Armstrong, R. 1998. ${ }^{87} \mathrm{Sr} /{ }^{86} \mathrm{Sr}$ ratios in modern and fossil food-webs of the Sterkfontein Valley. Geochimica et Cosmochimica Acta 62: 2463-73.

Solounias, N. and Hayek, L-A. 1993. New methods of tooth microwear analysis and application to dietary determination of two extinct antelopes. Journal of Zoology London 229: 421-45.

Solounias, N. and Moelleken, S. 1992. Tooth microwear analysis of Eotragus sansaniensis (Mammalia: Ruminantia), one of the oldest known bovids. Journal of Vertebrate Paleontology 12: 113-21.

Stimpson, C., Lister, A., Parton, A., Clark-Balzan, L., Breeze, P., Drake, N., Groucutt, H., Jennings, R., Scerri, E., White, T., Zahir, M., Duval, M., Grün, R., Al-Omari, A., Al-Murayyi, K., Zalmout, I., Mufarreh, Y., Memesh, A. and Petraglia, M. 2016. Middle Pleistocene vertebrate fossils from the Nefud Desert, Saudi Arabia. Quaternary Science Reviews 143: 13-36.

Tchernov, E. 1997. Are Late Pleistocene environmental factors, faunal changes and cultural transformations causally connected? Paléorient 23(2): 209-28.

Tieszen, L. 1991. Natural variations in the carbon isotope values of plants: implications for archaeology, ecology and paleoecology. Journal of Archaeological Science 18: 227-48.

Tornero, C., Ballase, M., Ughetto-Monfrin, J., Molist, M. and Sana, M. 2017. Evaluating seasonality of births in gazelles in the Middle Euphrates Valley: confirming ethological assumptions in the Abu Hureyra model. In, Rowley-Conwy, P., Sergeantson, D., and Halstead P. (eds), Economic Zooarchaeology: Studies in Hunting, Herding and Early Agriculture: 173-82. Oxford: Oxbow books.

Ungar, P. 2002. Microwear Image Analysis Software, Version 4.02 (04.10.02). Buffalo Edition (Retrieved 10.01.05).

United Nations Development Programme 1966. General Report on the Ground-Water Investigation of the Azraq Basin. New York: United Nations.

van Zeist, W., Baruch, U. and Bottema, S. 2009. Holocene palaeoecology of the Hula area, northeastern Israel. In, Kaptijn, E. and Petit, L. P. (eds), A Timeless Vale: 29-64. Archaeological Studies Leiden University 19. Leiden: Leiden University Press.

Vigne, J.-D. and Helmer, D. 2007. Was milk a 'secondary product' in the Old World Neolithisation process? Its 
role in the domestication of cattle, sheep and goats. Anthropozoologica 42: 9-40.

Vogel, J., Fuls, A. and Danin, A. 1986. Geographical and environmental distribution of $\mathrm{C}_{3}$ and $\mathrm{C}_{4}$ grasses in the Sinai, Negev, and Judean deserts. Oecologia 70: 258-65.

von den Driesch, A. and Wodtke, U. 1997. The fauna of 'Ain Ghazal, a major PPN and early PN settlement in Central Jordan. In, Gebel, H., Kafafi, Z. and Rollefson, G. (eds), The Prehistory of Jordan, II. Perspectives from 1997: 511-55. Berlin: ex oriente.

Wacher T., Wronski T., Hammond R., Winney, B., Blacket, M., Hundertmark, K., Mohammed, O., Omer, S., Macasero, W., Lerp, H., Plath, M., Bleidorn, C. 2011. Phylogenetic analysis of mitochondrial DNA sequences reveals polyphyly in the goitered gazelle (Gazella subgutturosa). Conservation Genetics 12: 827-31.

Wasse, A. 1997. Preliminary results of an analysis of the sheep and goat bones from 'Ain Ghazal, Jordan. In, Gebel, H., Kafafi, Z. and Rollefson, G. (eds), The Prehistory of Jordan, II. Perspectives from 1997: 575-92. Berlin: ex oriente.

Wright K. I., Critchley P. and Garrard A. 2008. Stone bead technologies and early craft specialization. Insights from two Neolithic sites in eastern Jordan. Levant 40: 131-65.

Zeder, M. A., Bar-Oz, G., Rufolo, S. J. and Hole, F. 2013. New perspectives on the use of kites in mass-kills of Levantine gazelle: a view from northeastern Syria. Quaternary International 297: 110-25.

Zhevnerov, V. 1984. The Persian gazelle on Barsakel'mes Island. Alma Ata: Hayka. [In Russian.] 


\section{Figures}

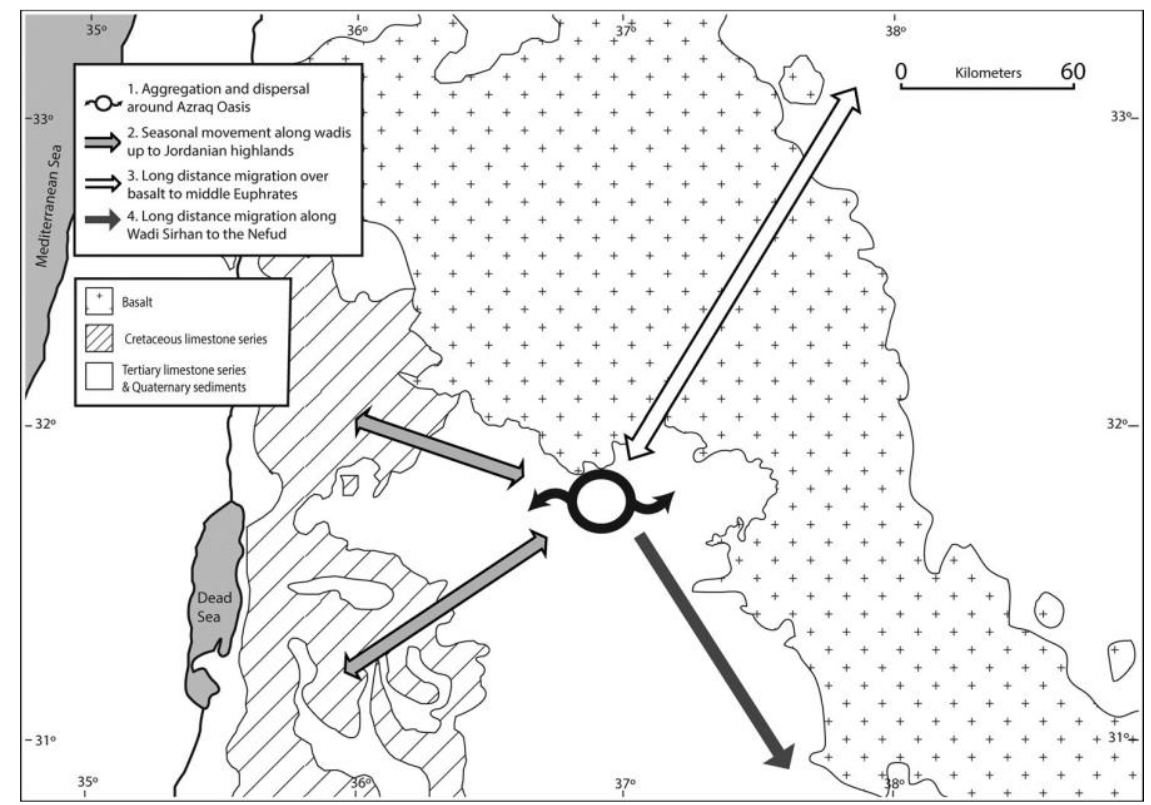

Figure 1. Map showing modelled gazelle mobility patterns and the main geological substrates in and around the Azraq Oasis (from Henton et al. 2018).

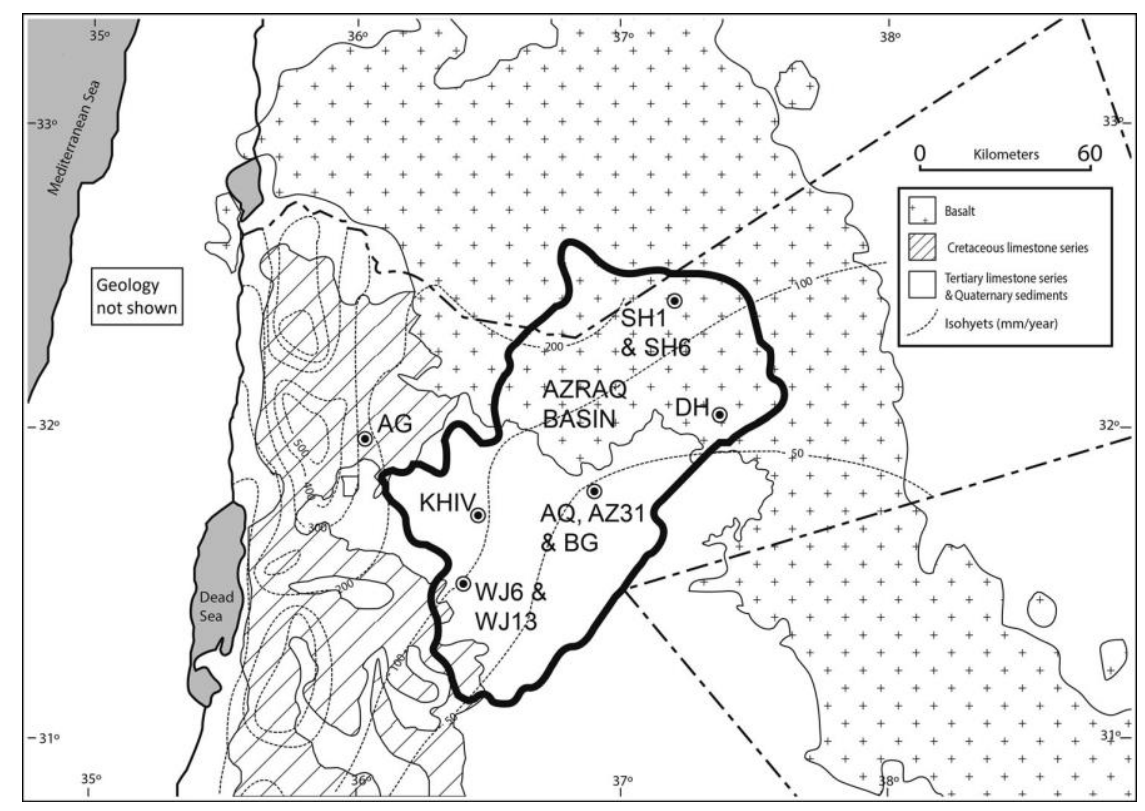

Figure 2. Map showing the sites studied and the Azraq Basin. AG 'Ain Ghazal, AQ Ayn Qasiyya, AZ31 Azraq 31, BG Bawwab al-Ghazal, DH Dhuweila, KHIV Kharaneh IV, SHI and 6 Shubayqa 1 and 6, WJ6 and 13 Wadi Jilat 6 and 13. 


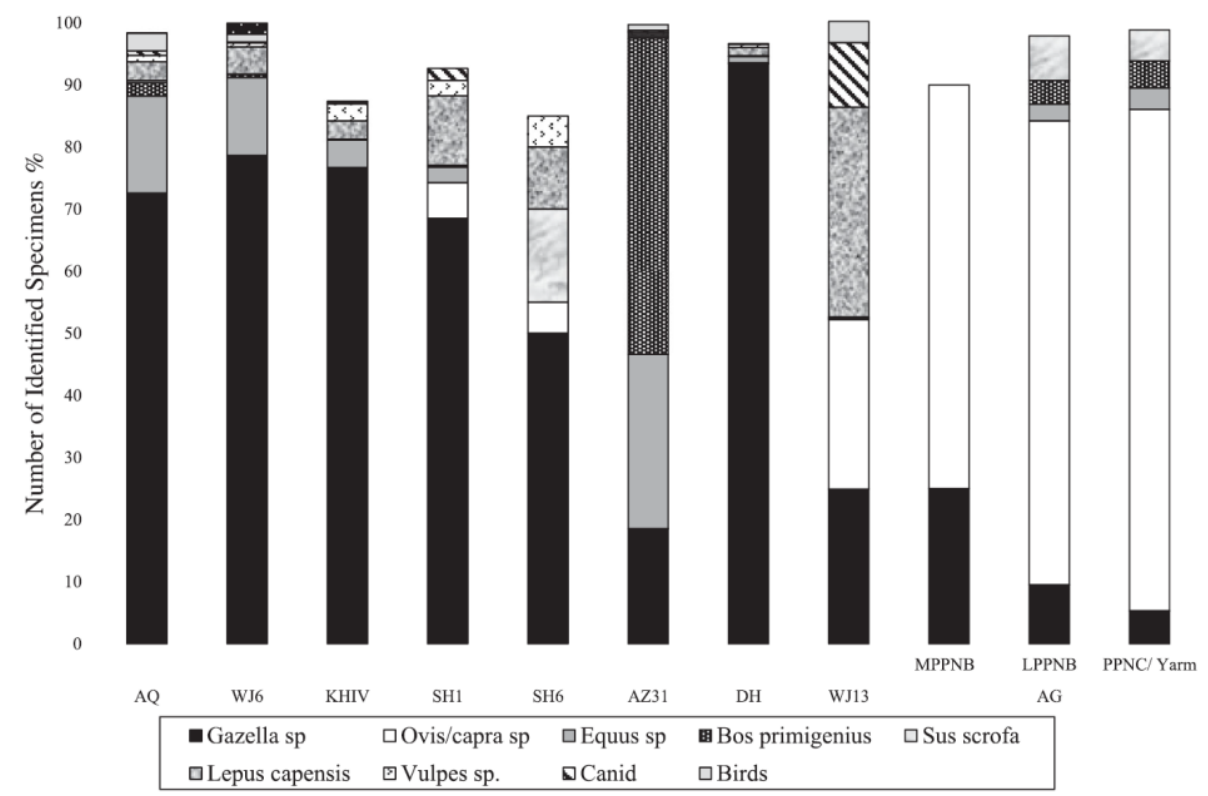

Figure 3. Histogram of the NISP\% of main food species retrieved from the studied sites, with gazelle represented in black and caprines in white. NISP\% either as published or calculated from NISP numbers.

Figures for SH6 are from a preliminary analysis. Horncore evidence indicates $G$ subgutturosa at KHIV and AQ; and $G$ gazella at AG. 

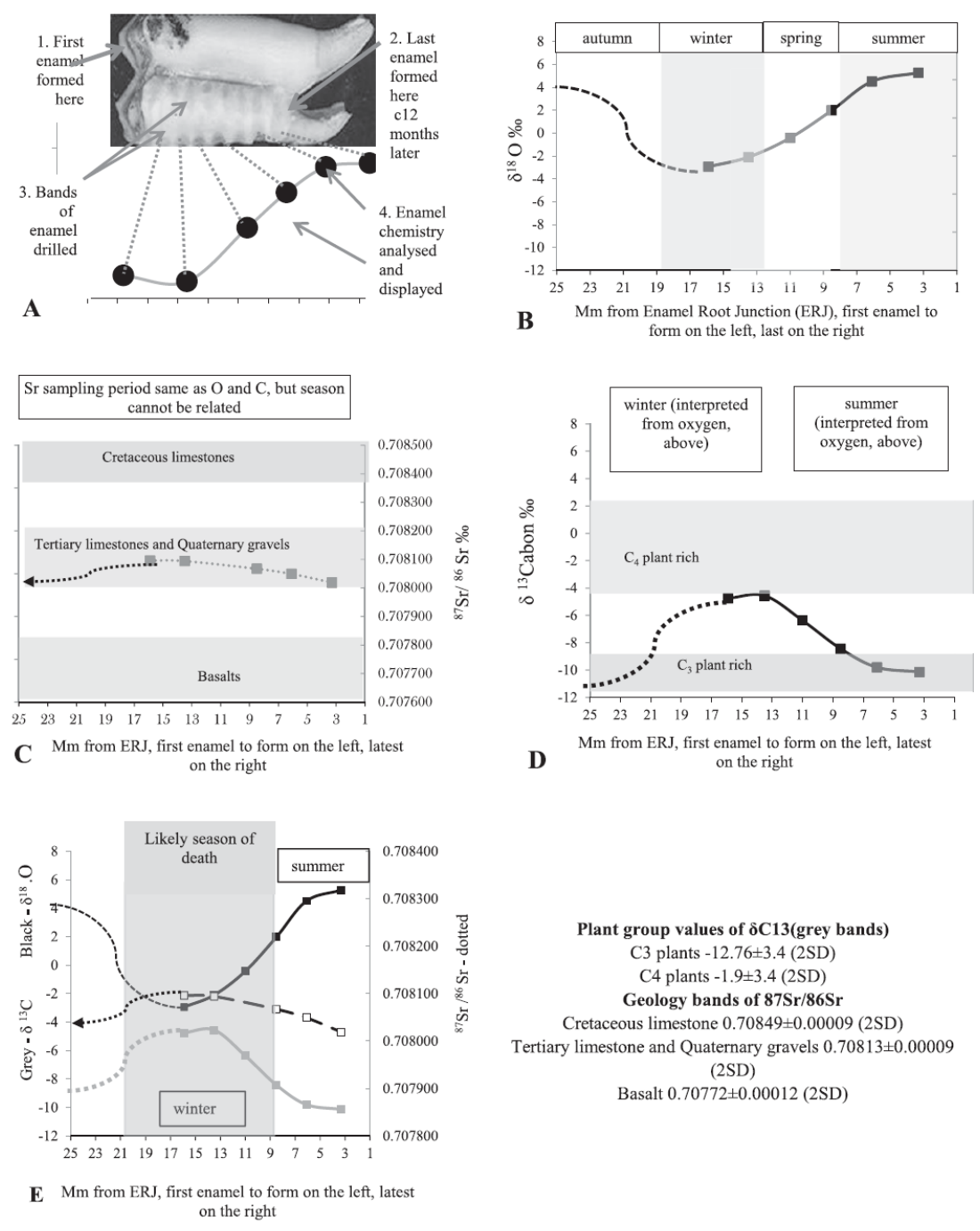

$$
\begin{gathered}
\text { Plant group values of } \delta \mathbf{C} 13 \text { (grey bands) } \\
\text { C3 plants }-12.76 \pm 3.4 \text { (2SD) } \\
\text { C4 plants }-1.9 \pm 3.4(2 \mathrm{SD}) \\
\text { Geology bands of } 87 \mathrm{Sr} / \mathbf{8 6 S r} \\
\text { Cretaceous limestone } 0.70849 \pm 0.00009 \text { (2SD) } \\
\text { Tertiary limestone and Quaternary gravels } 0.70813 \pm 0.00009 \\
\text { (2SD) } \\
\text { Basalt } 0.70772 \pm 0.00012(2 \mathrm{SD})
\end{gathered}
$$

Figure 4. Summary of how environmental information may be inferred from isotopic data in drilled ungulate tooth enamel samples. A. Tooth with sequentially drilled samples showing hypothetical curve generated from isotope values of the sample. B. $\left(\delta^{18} \mathrm{O}\right), \mathrm{C}\left({ }^{87} \mathrm{Sr} /{ }^{86} \mathrm{Sr}\right)$ and $\mathrm{D}\left(\delta^{13} \mathrm{C}\right)$ curves generated from Ayn Qasiyya tooth specimen 14. Y-axis values and seasonality interpretation based on the baseline established in Henton et al. (2018). E. Dental microwear evidence (rich in pits) of a browse-rich winter cull some years after enamel formed, superimposed on enamel isotope curves. 

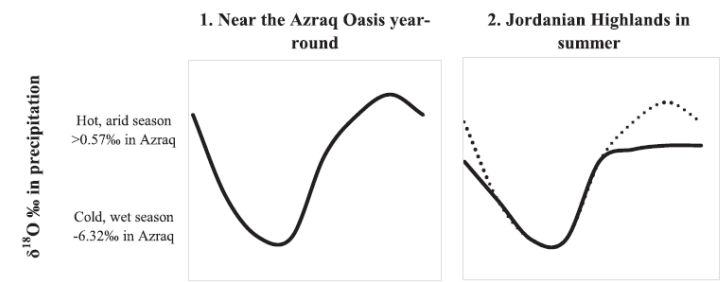

3. Mid-Euphrates in summer

4. Wadi Sirhan/ Nefud in
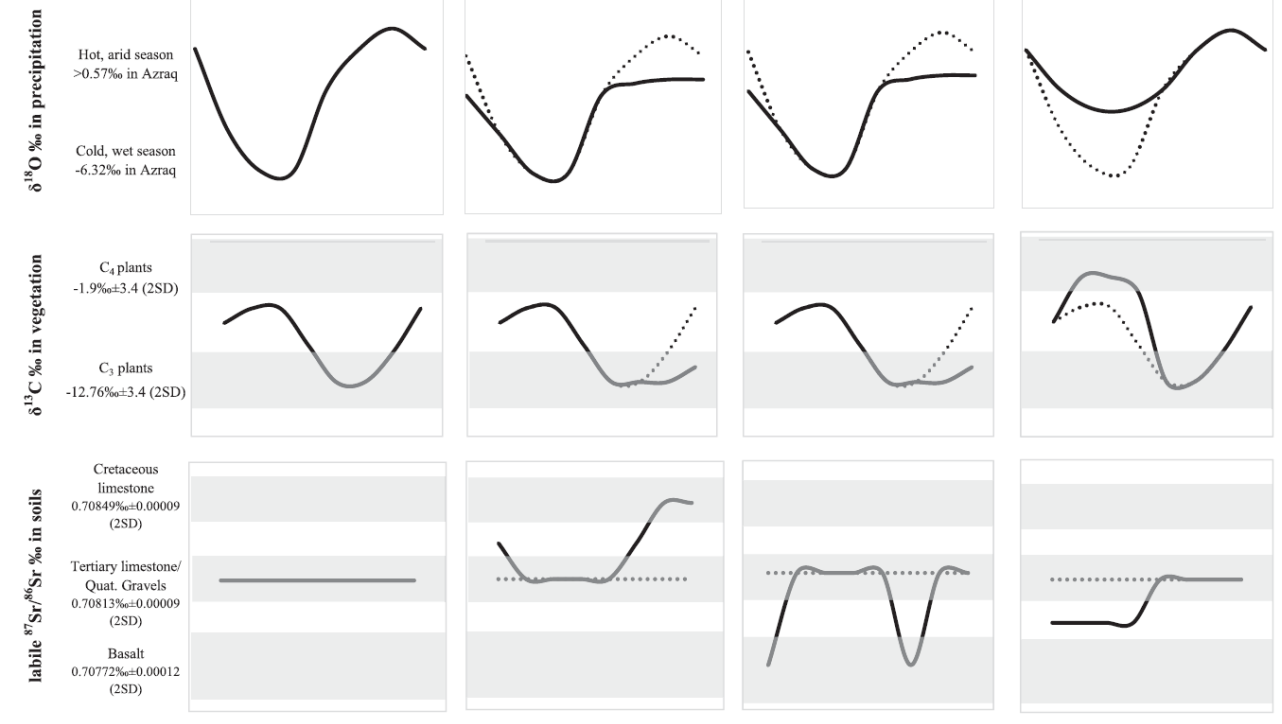

Figure 5. Modelled seasonal changes in isotope readings that would be expected under each of the four proposed gazelle mobility patterns (from Henton et al. 2018). Columns show each mobility pattern, rows show each isotope. Each box shows the modelled isotopic reading for a mobility pattern starting on the left in early autumn, through winter, spring and summer, and ending on the right in late summer. Dotted lines in Models 2, 3 and 4 show the modelled isotopic changes from Model 1 for comparison. 

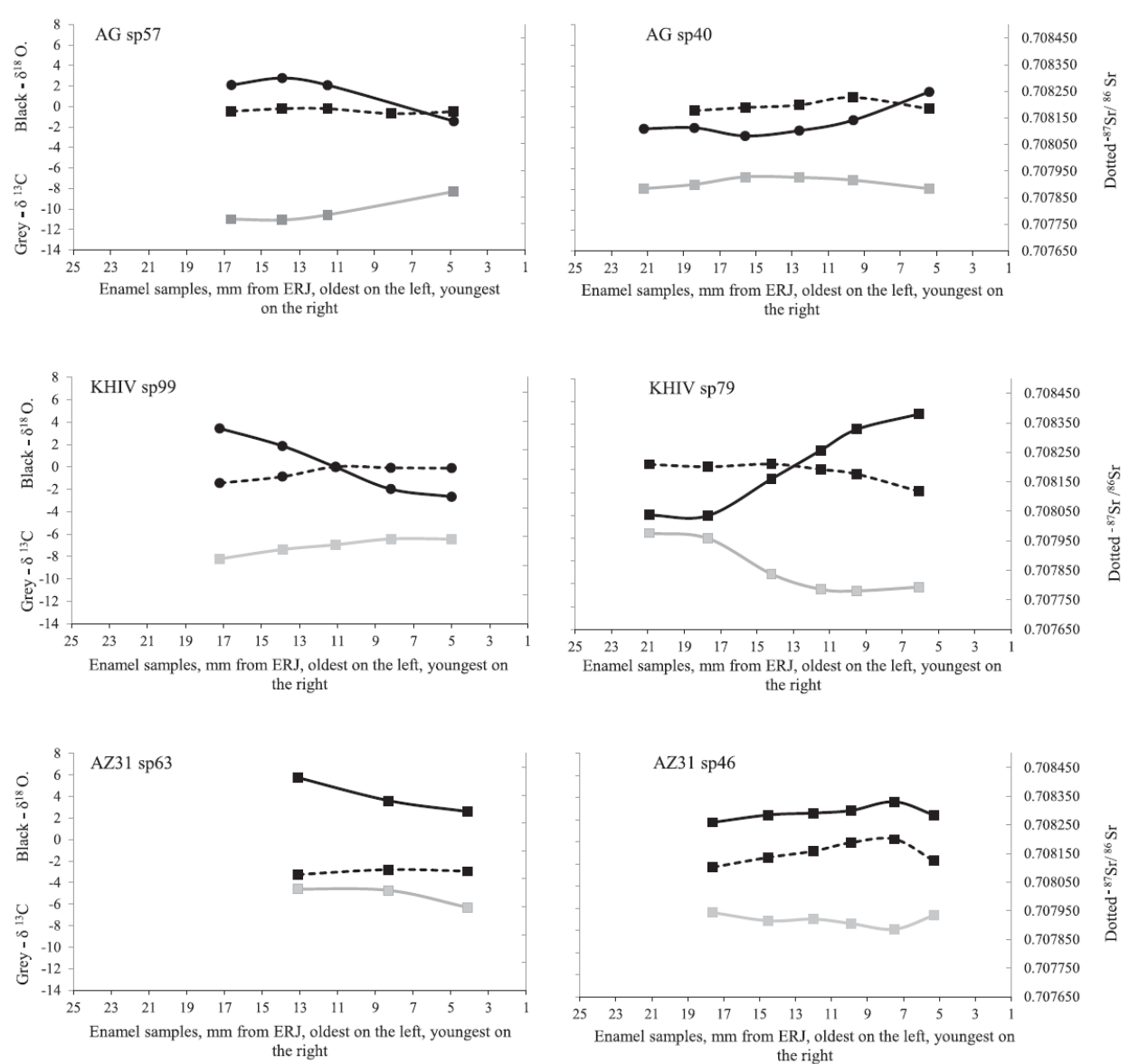

Figure 6. Results from 3 gazelles with both $\mathrm{M}_{2} \mathrm{~s}$ (left) and $\mathrm{M}_{3} \mathrm{~s}$ (right), showing how the isotope-constructed curves of the $\mathrm{M}_{3}$ follows that of the $\mathrm{M}_{2}$. 

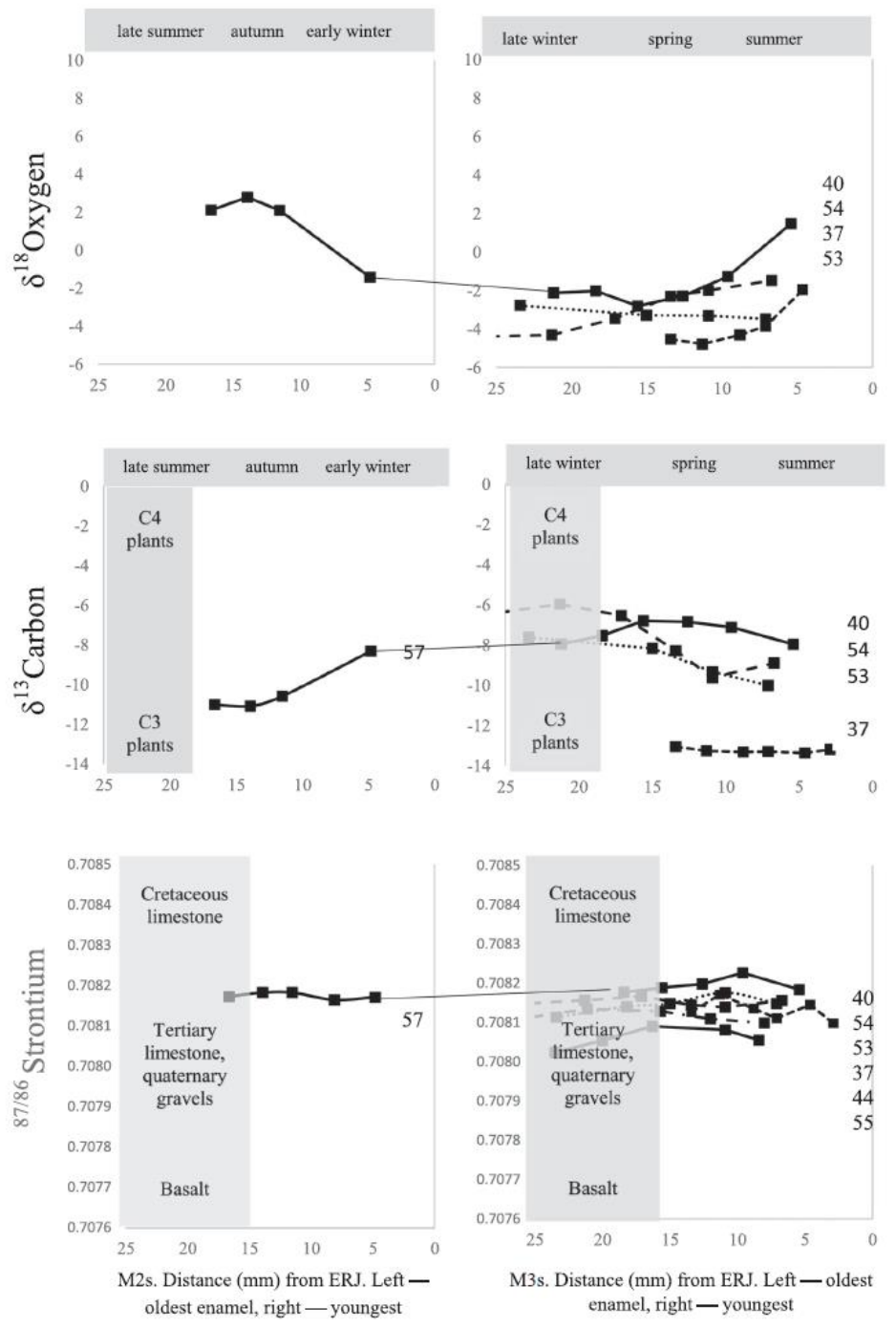

Figure 7. 'Ain Ghazal results for all isotopes for all analysed teeth. The $\mathrm{M}_{2} \mathrm{~s}$ are on the left, and the $\mathrm{M}_{3} \mathrm{~s}$ on the right. The top row shows the oxygen isotope datasets as evidence of seasonal weather, the middle row shows the carbon isotope datasets as evidence of seasonal food intake, and the bottom row shows strontium isotope datasets as evidence of seasonal location and movement. See Fig. 5 for details of the isotopic signatures for the main plant groups and geological formations (grey bands). 

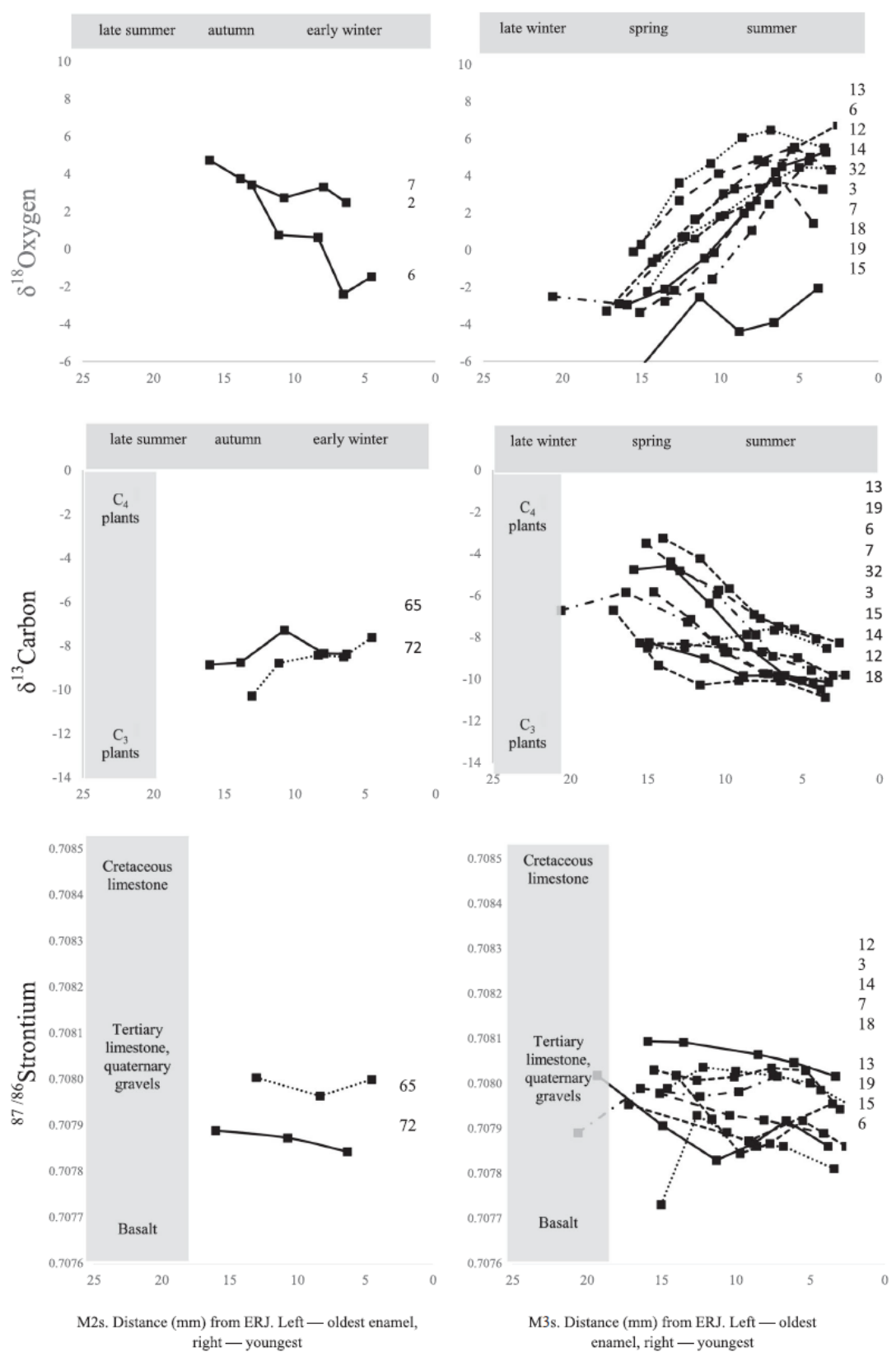

Figure 8. Ayn Qasiyya results for all isotopes for all analysed teeth. The $\mathrm{M}_{2} \mathrm{~S}$ are on the left, and the $\mathrm{M}_{3} \mathrm{~S}$ on the right. The top row shows the oxygen isotope datasets as evidence of seasonal weather, the middle row shows the carbon isotope datasets as evidence of seasonal food intake, and the bottom row shows strontium isotope datasets as evidence of seasonal location and movement. See Fig. 5 for details of the isotopic signatures for the main plant groups and geological formations (grey bands). 

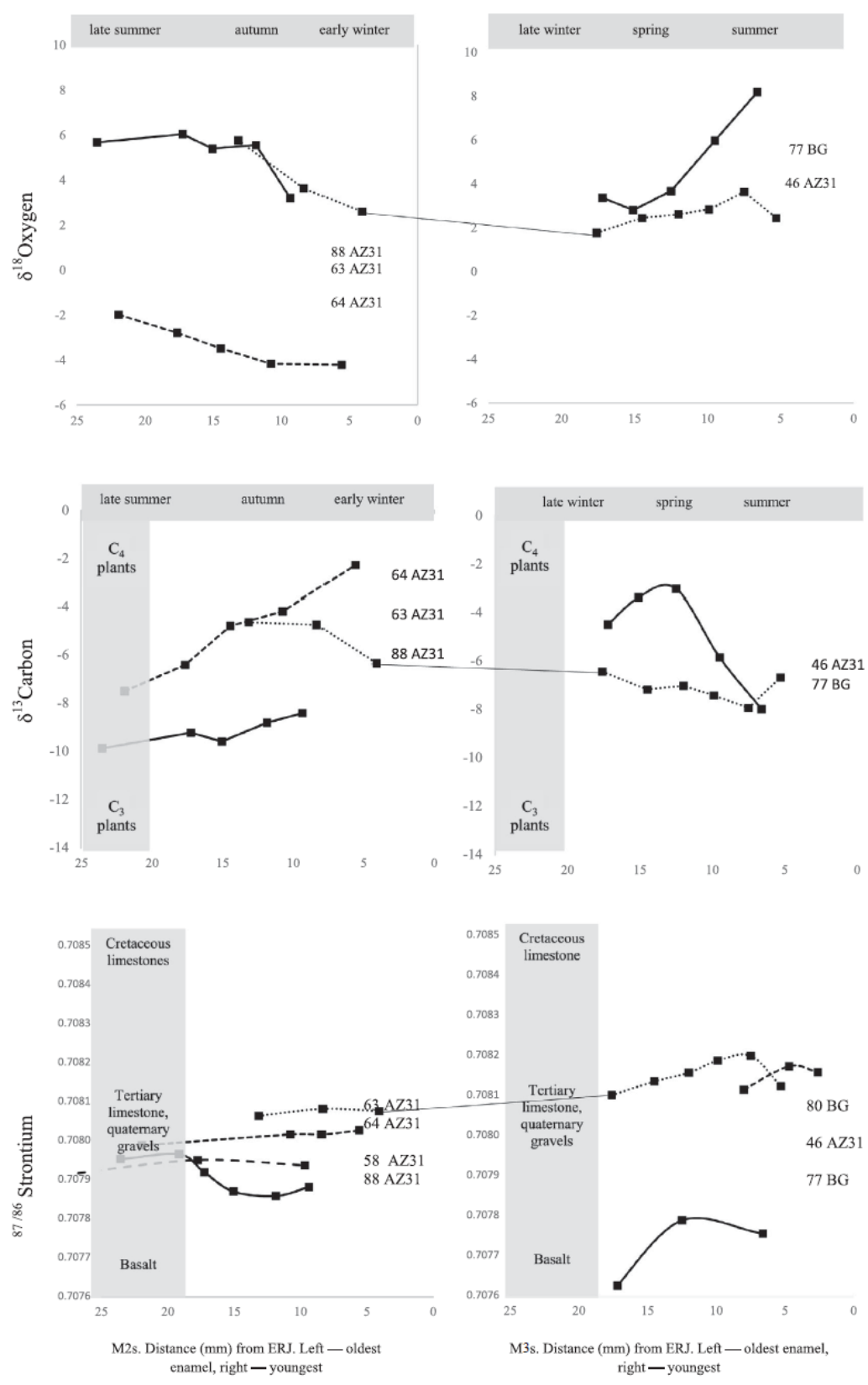

Figure 9. Azraq 31 and Bawwab al-Ghazal results for all isotopes for all analysed teeth. The $\mathrm{M}_{2} \mathrm{~s}$ are on the left, and the $\mathrm{M}_{3} \mathrm{~s}$ on the right. The top row shows the oxygen isotope datasets as evidence of seasonal weather, the middle row shows the carbon isotope datasets as evidence of seasonal food intake, and the bottom row shows strontium isotope datasets as evidence of seasonal location and movement. See Fig. 5 for details of the isotopic signatures for the main plant groups and geological formations (grey bands). 


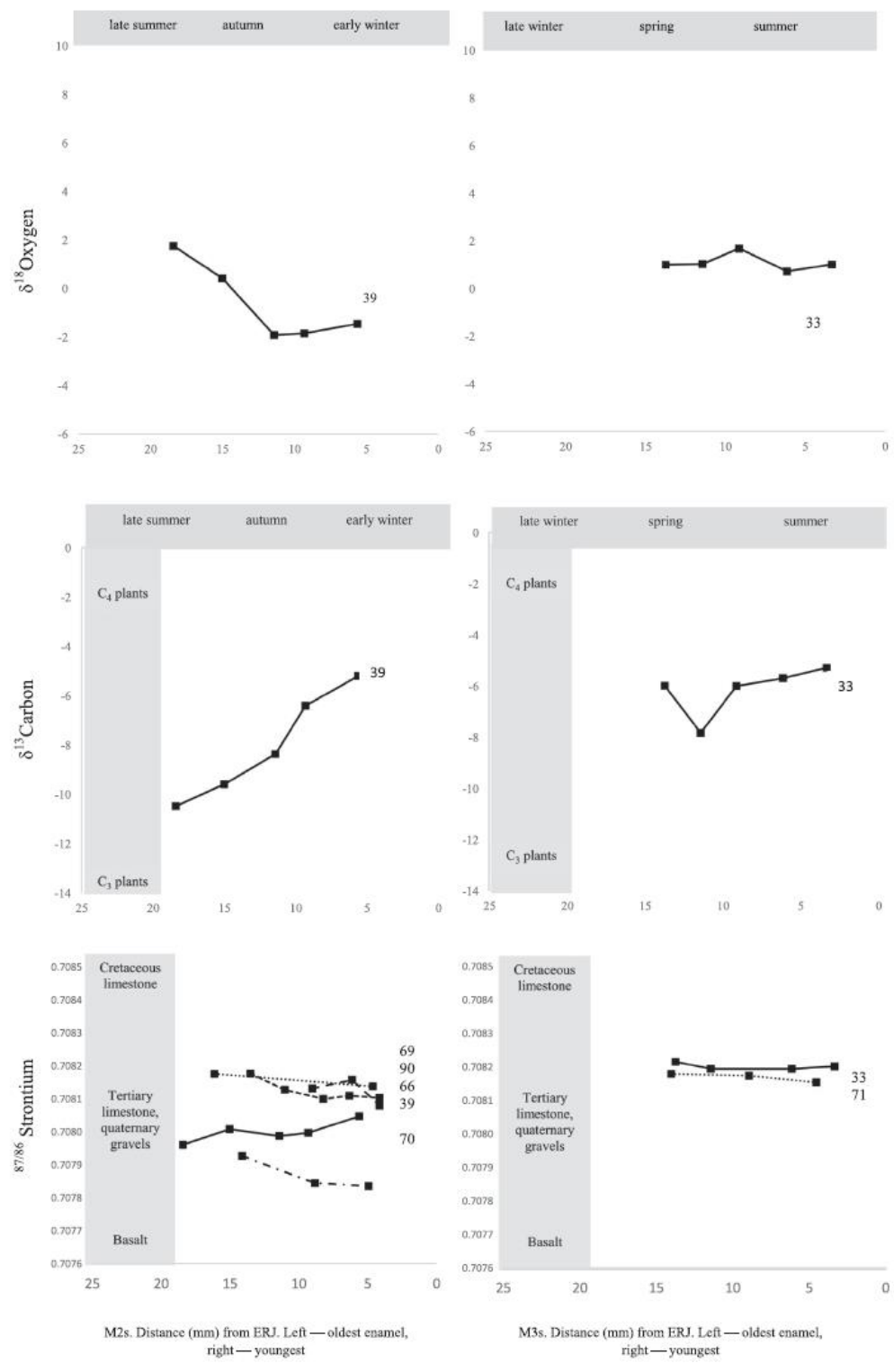

Figure 10. Dhuweila results for all isotopes for all analysed teeth. The $\mathrm{M}_{2} \mathrm{~s}$ are on the left, and the $\mathrm{M}_{3} \mathrm{~s}$ on the right. The top row shows the oxygen isotope datasets as evidence of seasonal weather, the middle row shows the carbon isotope datasets as evidence of seasonal food intake, and the bottom row shows strontium isotope datasets as evidence of seasonal location and movement. See Fig. 5 for details of the isotopic signatures for the main plant groups and geological formations (grey bands). 

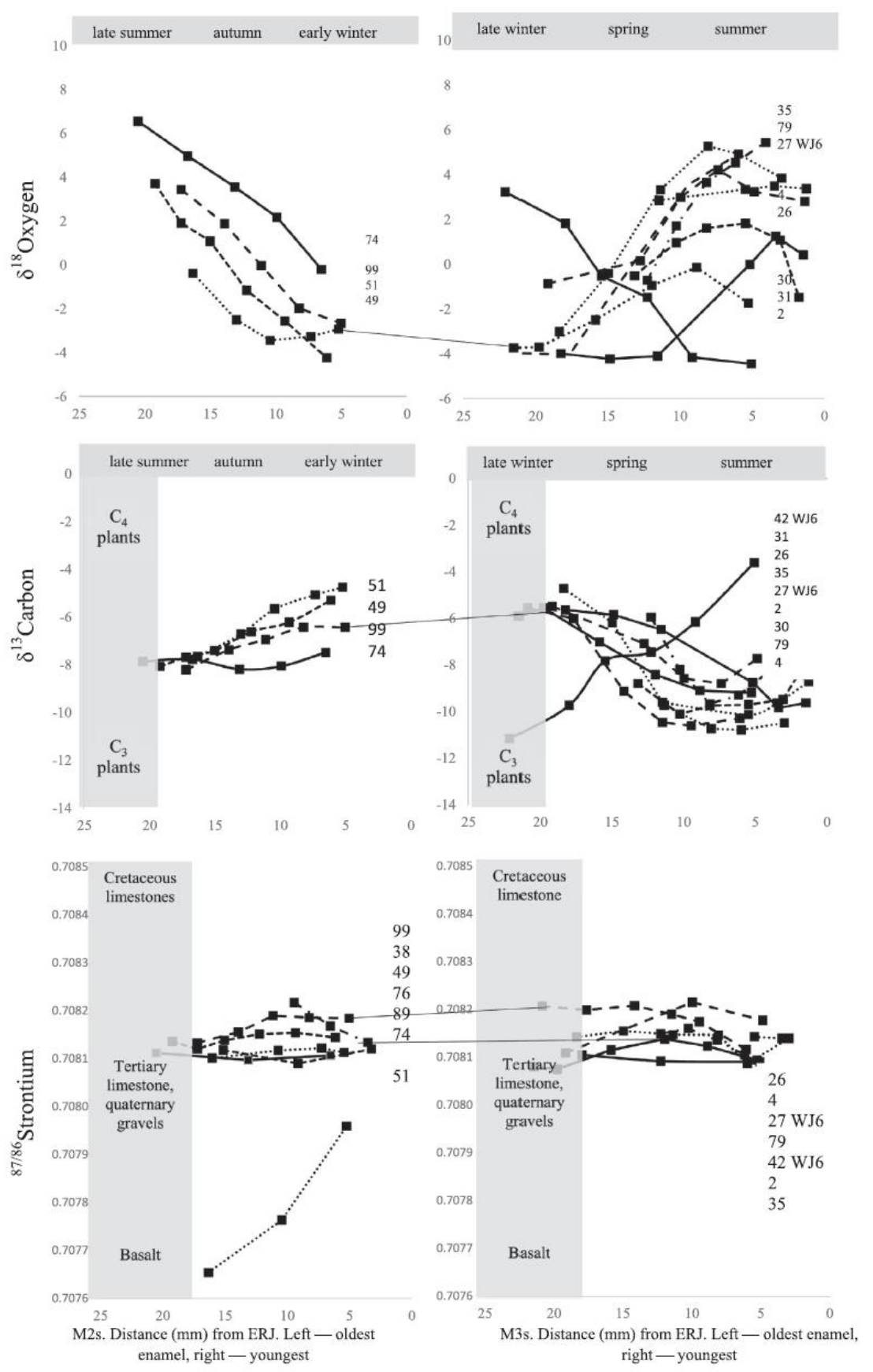

Figure 11. Kharaneh IV and Wadi Jilat 6 results for all isotopes for all analysed teeth. The $\mathrm{M}_{2} \mathrm{~s}$ are on the left, and the $\mathrm{M}_{3} \mathrm{~s}$ on the right. The top row shows the oxygen isotope datasets as evidence of seasonal weather, the middle row shows the carbon isotope datasets as evidence of seasonal food intake, and the bottom row shows strontium isotope datasets as evidence of seasonal location and movement. See Fig. 5 for details of the isotopic signatures for the main plant groups and geological formations (grey bands). 

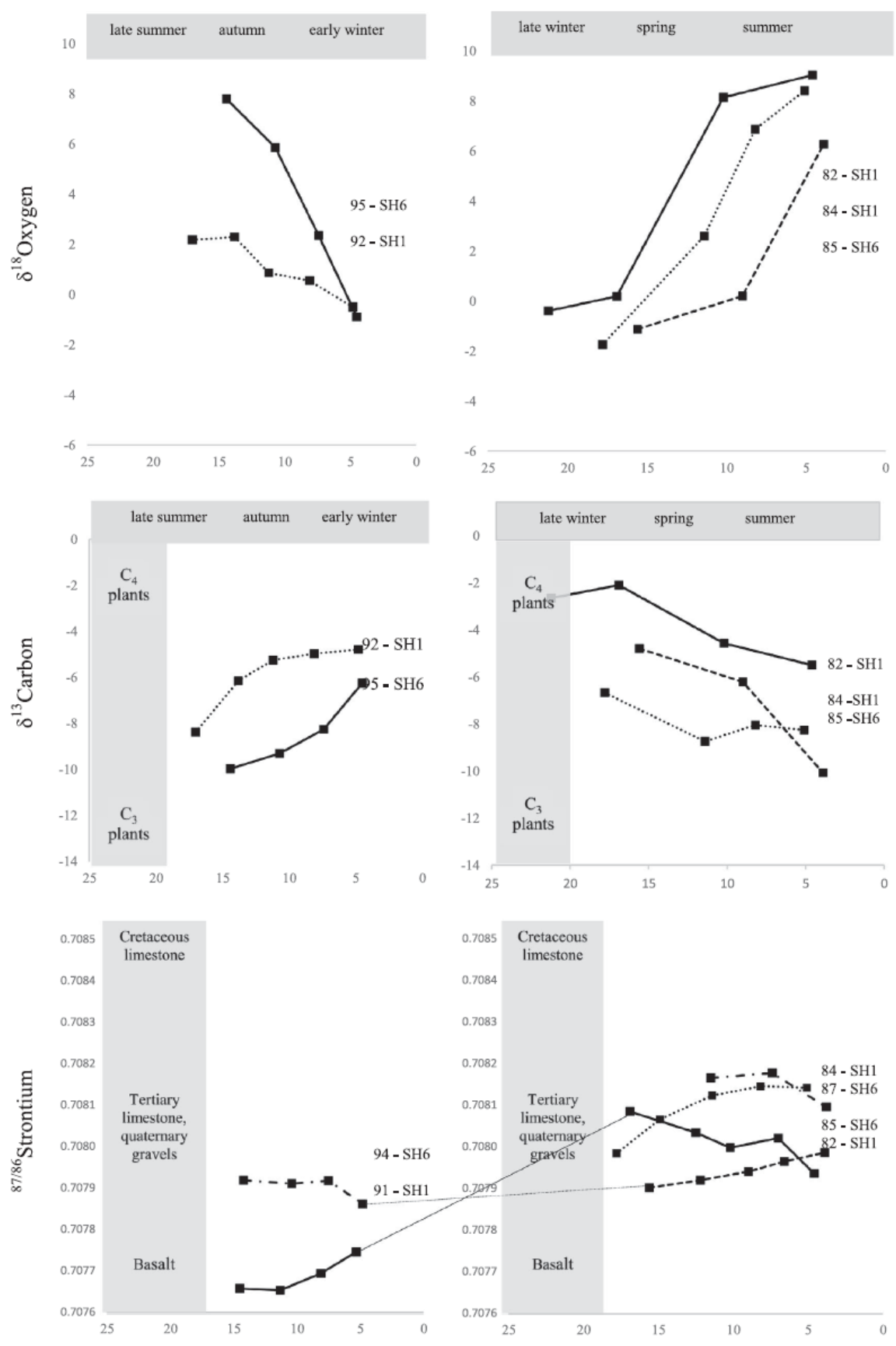

M2s. Distance (mm) from ERJ. Left —oldest enamel, right - youngest

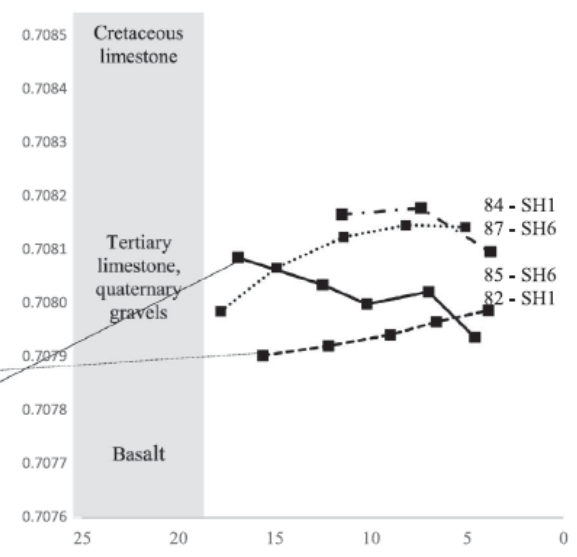

M3s. Distance (mm) from ERJ. Left — oldest enamel, right - youngest

Figure 12. Shubayqa 1 and Shubayqa 6 results for all isotopes for all analysed teeth. The $\mathrm{M}_{2} \mathrm{~s}$ are on the left, and the $\mathrm{M}_{3} \mathrm{~s}$ on the right. The top row shows the oxygen isotope datasets as evidence of seasonal weather, the middle row shows the carbon isotope datasets as evidence of seasonal food intake, and the bottom row shows strontium isotope datasets as evidence of seasonal location and movement. See Fig. 5 for details of the isotopic signatures for the main plant groups and geological formations (grey bands). 


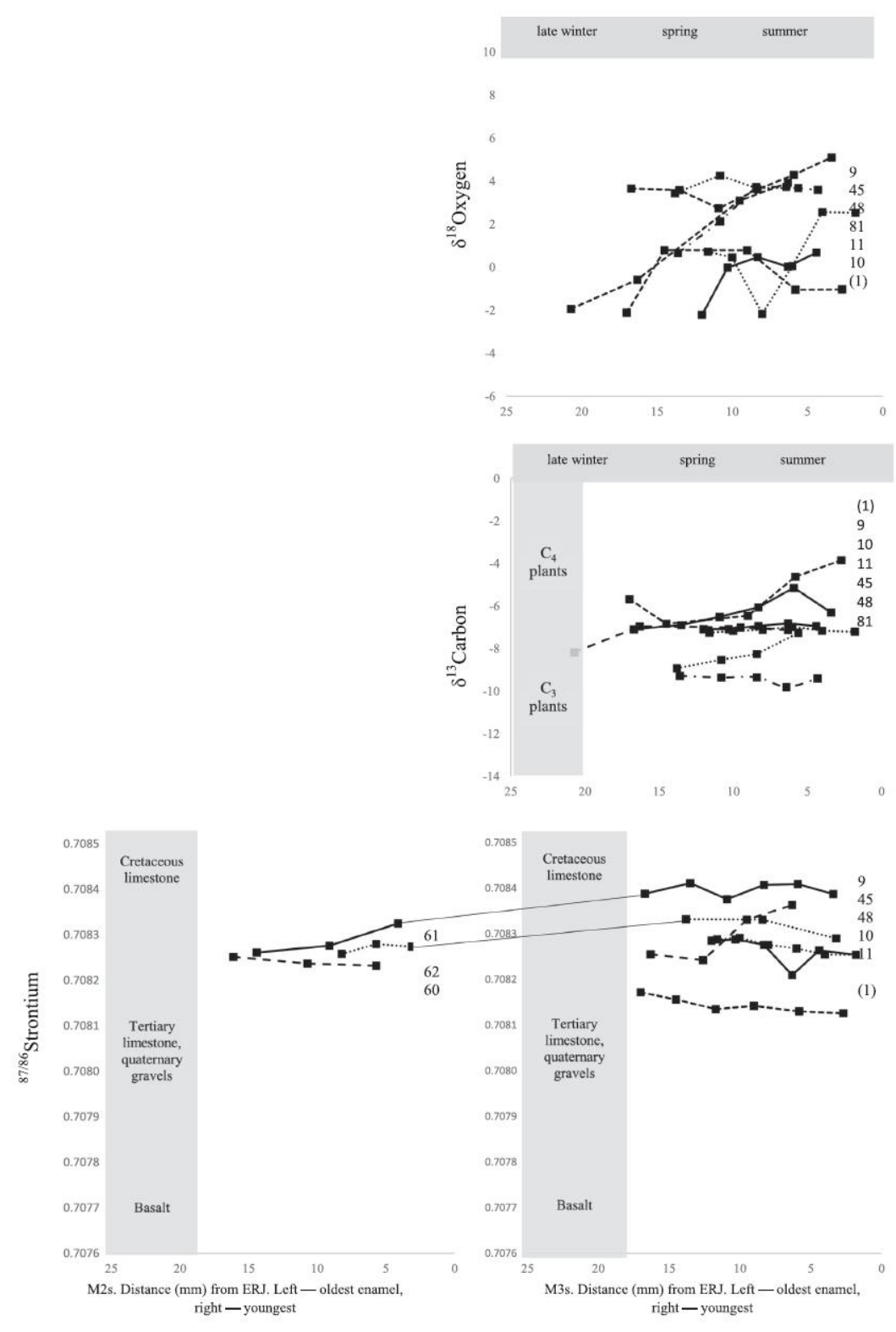

Figure 13. Wadi Jilat 13 results for all isotopes for all analysed teeth. The $\mathrm{M}_{2} \mathrm{~s}$ are on the left, and the $\mathrm{M}_{3} \mathrm{~S}$ on the right. The top row shows the oxygen isotope datasets as evidence of seasonal weather, the middle row shows the carbon isotope datasets as evidence of seasonal food intake, and the bottom row shows strontium isotope datasets as evidence of seasonal location and movement. See Fig. 5 for details of the isotopic signatures for the main plant groups and geological formations (grey bands). 


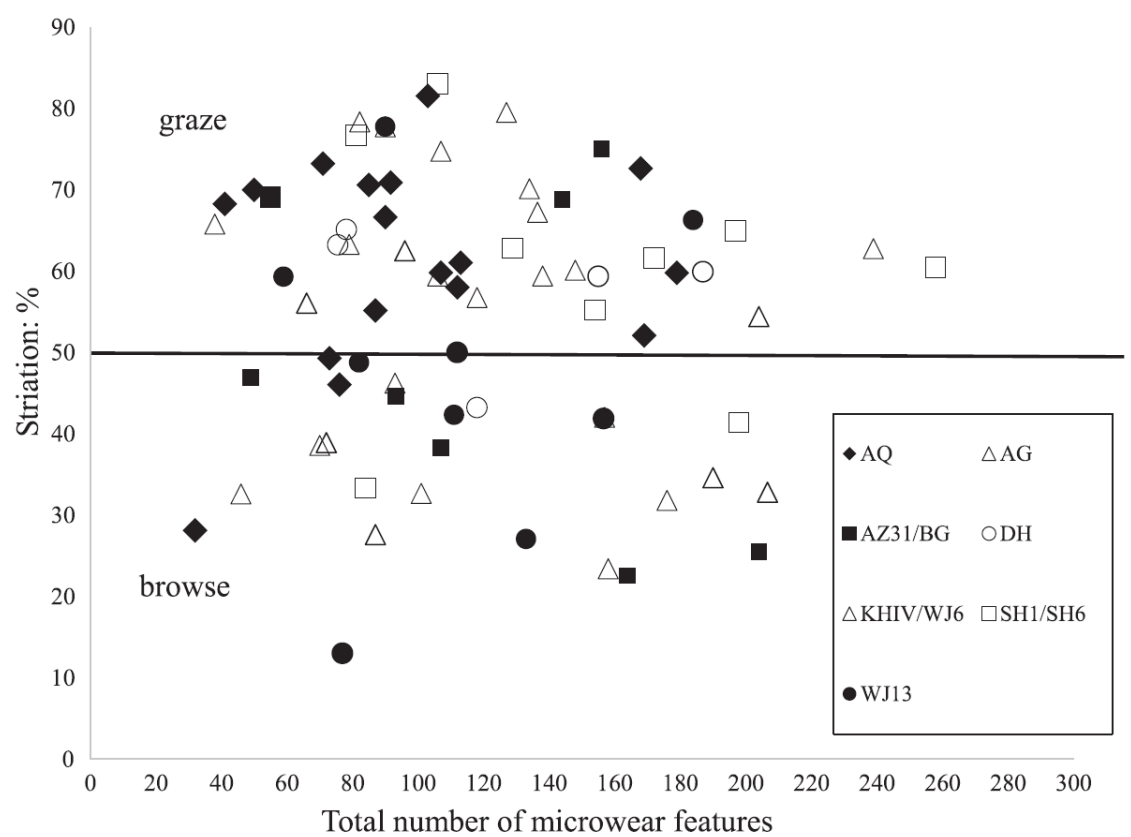

Figure 14. Dental microwear for all specimens sorted by symbols. Total number of features on the $\mathrm{x}$-axis and striation $\%$ on the y-axis.

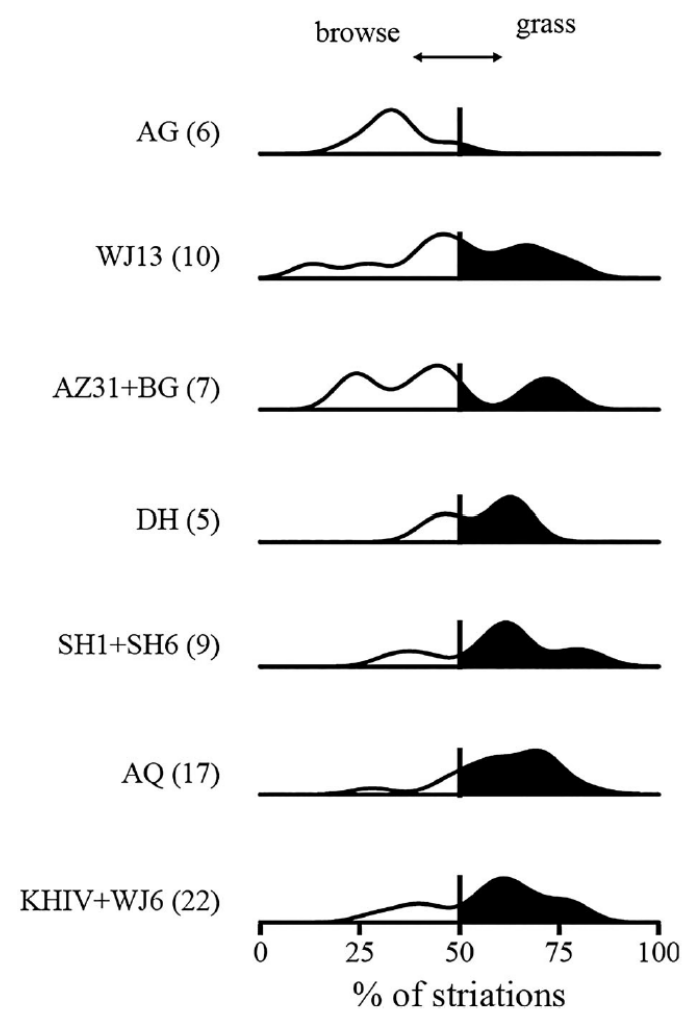

Figure 15. Kernel density plot (5\% kernel size) showing distribution of the proportion of microwear striations in specimens grouped into analytical site cohorts. Specimens to the left (white) of each central $50 \%$ line died on a diet rich in the soft browse of late summer, autumn and winter, those on the right (black) died on the fibrous grass-rich diet of late winter, spring and early summer. 

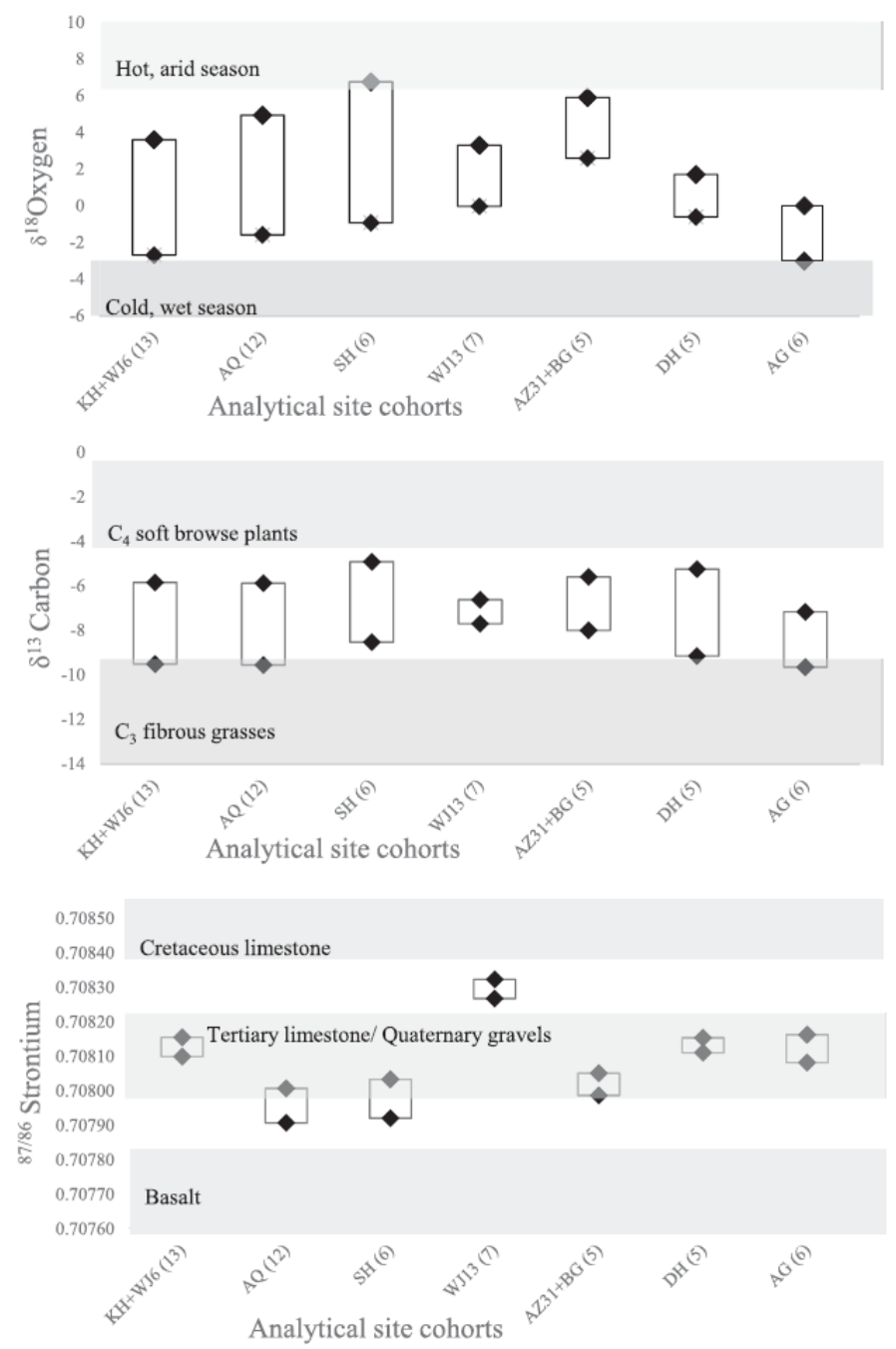

Figure 16. Averaged maxima, minima and ranges of each isotope for Early/Middle Epipalaeolithic and PPNB/Later Neolithic analytical cohorts (after removal of incomplete curves, and all outlier data). Arranged in broad chronology. See Fig. 5 for details of bandings. 
Tables

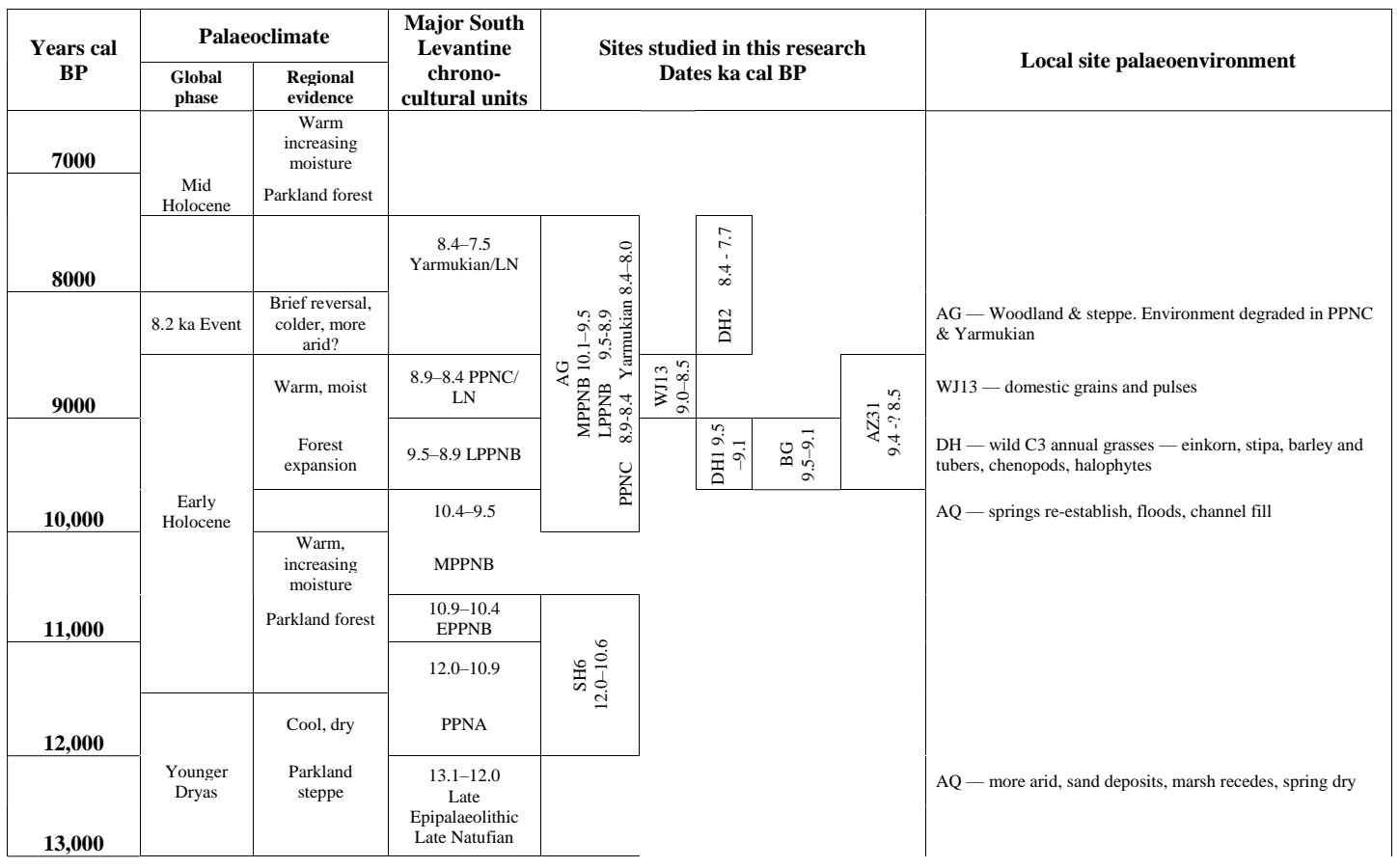

Table 1. Summarized chronology of global and regional palaeoclimate changes, and the local industries and dates of studied Epipalaeolithic and Neolithic sites in and around the north-east Jordan Badia.

\begin{tabular}{|c|c|c|c|c|c|c|}
\hline \multicolumn{2}{|c|}{$\begin{array}{c}\text { Site } \\
\text { with sources }\end{array}$} & Location & $\begin{array}{l}\text { Present local } \\
\text { environment }\end{array}$ & Dating & Material culture & Economy \\
\hline \multirow{6}{*}{ 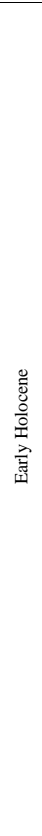 } & $\begin{array}{l}\text { 'Ain Ghazal } \\
14,30,32,33\end{array}$ & \begin{tabular}{|l|} 
PPNB $121,400 \mathrm{~m}^{2}$ \\
725 masl \\
Cretaceous limestone \\
Jordanian Highlands. Near \\
spring on Wadi Zarqa
\end{tabular} & $\begin{array}{l}250 \mathrm{~mm} \text { isohyet. Open } \\
\text { oak park woodland/open } \\
\text { steppe boundary. Wadi } \\
\text { reed-fringed }\end{array}$ & $\begin{array}{l}\text { MPPNB 10.1-9. ka cal BP } \\
\text { LPPNB 9.5-8.9 ka cal BP } \\
\text { PPNC 8.9-8.4 ka cal BP } \\
\text { Yarmoukian 8.4-7.5 ka cal } \\
\text { BP }\end{array}$ & $\begin{array}{l}\text { Growing through MPPNB \& } \\
\text { LPPNB. Large site with } \\
\text { elaborate architecture, public } \\
\text { buildings, mortuary, symbolic } \\
\text { remains. Declining from PPNC, } \\
\text { less cultivation/increased } \\
\text { pastoralism? }\end{array}$ & $\begin{array}{l}\text { MPPNB goat hunted or } \\
\text { managed, LPPNB replaced } \\
\text { with domestic sheep, hunted } \\
\text { boar and gazelle. Domestic } \\
\text { pulses and grains }\end{array}$ \\
\hline & $\begin{array}{c}\text { Wadi Jilat } 13 \\
6,8,10,13\end{array}$ & \begin{tabular}{|l|}
$800 \mathrm{~m}^{2}$ \\
785 masl \\
Limestone steppe. On Wadi \\
Jilat terrace overlooking \\
gorge and seasonal pools
\end{tabular} & $\begin{array}{l}100 \mathrm{~mm} \text { isohyet. } \\
\text { Steppe/desert boundary. } \\
\text { Silty soils on terrace. } \\
\text { Reeds and shrubs by } \\
\text { seasonal wadi pools } \\
\text { draining from } 972 \text { masl }\end{array}$ & ELN $9.0-8.5 \mathrm{ka}$ cal BP & $\begin{array}{l}\text { Semi-subterranean, curvilinear } \\
\text { structures, figurines, } \\
\text { engravings, dressed pillars, } \\
\text { burins, grinding stones, } \\
\text { imported marble beads, shell } \\
\text { beads, bone tools }\end{array}$ & $\begin{array}{l}\text { Gazelle, caprine and hare } \\
\text { dominate equally. Sedges, figs, } \\
\text { pulses and cultivated grains } \\
\text { (possibly locally grown) }\end{array}$ \\
\hline & $\begin{array}{c}\text { Bawwab al- } \\
\text { Ghazal } \\
20,29\end{array}$ & \begin{tabular}{|l|}
$1025 \mathrm{~m}^{2}$ \\
508 masl \\
Central Oasis. Near Azraq \\
Shishan by spring-fed \\
marshlands on playa edge
\end{tabular} & $\begin{array}{l}\text { Active dunes near marsh } \\
\text { and seasonally flooded } \\
\text { playa, very salty silty soil. } \\
\text { Phragmites, tamasik, } \\
\text { halophytes }\end{array}$ & LPPNB $9.5-9.1 \mathrm{ka}$ cal BP & $\begin{array}{l}\text { Chipped stone, burin spawl, } \\
\text { Dabbah marble beads, hearths, } \\
\text { a number of floors and wind- } \\
\text { break stone foundations }\end{array}$ & $\begin{array}{l}\text { Gazelle dominate, also sheep } \\
\text { and bird. Possibly very early } \\
\text { hunter-herders }\end{array}$ \\
\hline & $\begin{array}{c}\text { Azraq 31 } \\
1,6,7,8,10 \\
11\end{array}$ & \begin{tabular}{|l|}
$4600 \mathrm{~m}^{2}$ \\
508 masl \\
Central Oasis. Near Azraq \\
Shishan springs between \\
marsh and playa
\end{tabular} & $\begin{array}{l}\text { Travertines by marshlands } \\
\text { on edge of seasonally } \\
\text { flooded playa. Soils salty } \\
\text { and silty. Phragmites, } \\
\text { tamarisk, halophytes }\end{array}$ & $\begin{array}{l}\text { LPPNB } 9.4-9.0 \mathrm{ka} \mathrm{cal} \mathrm{BP} \\
\text { ELN } 9.0-8.5 \mathrm{ka} \text { cal BP? }\end{array}$ & $\begin{array}{l}\text { LPPNB — hearths, cobble } \\
\text { platform, stone, shell and bone } \\
\text { beads, burins. } \\
\text { LN - structures, shaft } \\
\text { straighteners, mortars, barrel } \\
\text { and disc imported stone beads }\end{array}$ & $\begin{array}{l}\text { Gazelle dominate with equids } \\
\text { and auroch. Two caprine bones } \\
\text { from Late PPNB hint at early } \\
\text { herding. Sedge seed, some } \\
\text { cultivated barley. LN probably } \\
\text { hunter-herders }\end{array}$ \\
\hline & $\begin{array}{c}\text { Dhuweila } \\
2,3,13,19\end{array}$ & \begin{tabular}{|l|}
$7000 \mathrm{~m}^{2}$ \\
635 masl \\
Basalt boulder steppe. \\
Outcrop overlooking playa \\
of Wadi Dhuweila
\end{tabular} & $\begin{array}{l}<100 \mathrm{~mm} \text { isohyet. Dry } \\
\text { steppe. Seasonal flooding } \\
\text { of playa and flush of } \\
\text { annuals. }\end{array}$ & $\begin{array}{l}\text { DH - LPPNB 9.5-9.1 ka cal } \\
\text { BP } \\
\text { DH2 - ELN } 8.4-7.7 \mathrm{ka} \mathrm{cal} \\
\text { BP }\end{array}$ & $\begin{array}{l}\text { Walled structures, pits, hearths. } \\
\text { Animal bone, chipped and } \\
\text { basalt tools, arrowheads, burins, } \\
\text { rare sickle blades, charcoal. } \\
\text { Engraved stones, pavement. } \\
\text { (DH2 - Late Neolithic phase } \\
\text { possibly contemporary with kite } \\
\text { structure) }\end{array}$ & $\begin{array}{l}\text { PPNB gazelle dominate, no } \\
\text { caprine. Wild wheat and barley } \\
\text { remains }\end{array}$ \\
\hline & $\begin{array}{c}\text { Shubayqa } 6 \\
22,24,26,27, \\
34\end{array}$ & \begin{tabular}{|l|} 
PPNA \\
$3000 \mathrm{~m}^{2}$ \\
$740 \mathrm{masl}$ \\
Basalt boulder steppe. \\
Outcrop overlooking \\
extensive Shubayqa playa
\end{tabular} & $\begin{array}{l}<200 \mathrm{~mm} \text { isohyet. Wadi } \\
\text { Rajil channels huge } \\
\text { amounts of water } \\
\text { seasonally from Jebel } \\
\text { Druze, supporting flush of } \\
\text { annual plants }\end{array}$ & PPNA $12.0-10.6 \mathrm{ka}$ cal BP & $\begin{array}{l}\text { Series of circular and sub- } \\
\text { circular buildings, el-Khiam } \\
\text { points, basalt groundstone, } \\
\text { worked bone, many greenstone } \\
\text { beads, one figurine, incised } \\
\text { plaque. }\end{array}$ & Forthcoming \\
\hline
\end{tabular}

Table 2. Summary of information on the sites studied. 


\begin{tabular}{|c|c|c|c|c|}
\hline & \multirow[t]{2}{*}{ Site } & \multirow[t]{2}{*}{ Evidence } & \multicolumn{2}{|c|}{$\begin{array}{c}\text { Interpreted gazelle hunting season, assuming peak } \\
\text { birthing in spring }\end{array}$} \\
\hline & & & Spring/summer & Autumn/winter \\
\hline \multirow{5}{*}{ 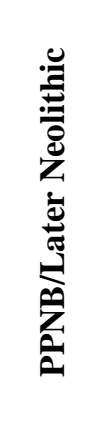 } & $\mathbf{A G}^{8}$ & BFD & None evident & Main \\
\hline & $\mathbf{W J} \mathbf{H}^{4}$ & $\begin{array}{l}\text { BFD, arable } \\
\text { scheduling }\end{array}$ & Extended seasons of occupation & None evident \\
\hline & DH $^{5}$ & BFD & Some & Possible \\
\hline & $\mathbf{A Z 3 1}^{9}$ & BFD & Probable & \\
\hline & $\mathbf{B G}^{10}$ & Birds & Some in spring & Main \\
\hline \multirow{2}{*}{ 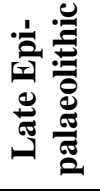 } & SH6 & Forthcoming & & \\
\hline & SH1 $^{9}$ & BFD, birds & Mainly birds & Main \\
\hline \multirow{3}{*}{ 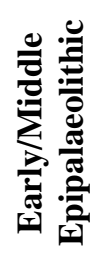 } & KHIV $^{1,3,7}$ & $\begin{array}{l}\text { BFD, TCS, } \\
\text { birds }\end{array}$ & Some & Main \\
\hline & $\mathrm{WJ}^{2}$ & BFD & Very little & Main \\
\hline & $A Q^{5,6}$ & BFD & Very little & Main \\
\hline \multicolumn{5}{|c|}{$\begin{array}{l}\text { Sources of information: } 1 \text { Jones 2012, } 2 \text { Martin 1994, } 3 \text { Martin et al. 2010, } 4 \text { Martin et al. 2013, } \\
5 \text { Martin et al. 2016; } 6 \text { Richter } \text { et al. 2009, } 7 \text { Richter et al. 2013, } 8 \text { von den Driesch and Wodtke } \\
\text { 1997, } 9 \text { Yeomans and Richter 2016; } 9 \text { Martin 1999; } 10 \text { Kinzelman } 2003\end{array}$} \\
\hline
\end{tabular}

Table 3. Published zooarchaeological seasonality evidence of hunting seasonality at sites studied. BFD — bone fusion data and new-born presence, TCS — tooth cementum studies. 


\begin{tabular}{|c|c|c|c|c|}
\hline & Limestone & Oasis & Basalt & Highlands \\
\hline \multirow{3}{*}{$\begin{array}{l}\text { PPNB } \\
\text { to EN }\end{array}$} & WJ13 & AZ31 & DH & AG \\
\hline & \multirow[t]{2}{*}{$\begin{array}{c}11 \text { teeth sampled from } 9 \text { individuals } \\
8 \mathrm{M}_{3} \text { and } 3 \mathrm{M}_{2} \\
\text { Microwear } 7 \mathrm{M}_{3} \text { and } 3 \mathrm{M}_{2} \\
\text { Carbon } 7 \mathrm{M}_{3} \\
\text { Strontium } 6 \mathrm{M}_{3} \text { and } 3 \mathrm{M}_{2}\end{array}$} & $\begin{array}{c}5 \text { teeth sampled from } 4 \text { individuals } \\
1 \mathrm{M}_{3} \text { and } 4 \mathrm{M}_{2} \\
\text { Microwear } 1 \mathrm{M}_{3} \text { and } 4 \mathrm{M}_{2} \\
\text { Carbon } 1 \mathrm{M}_{3} \text { and } 3 \mathrm{M}_{2} \\
\text { Strontium } 1 \mathrm{M}_{3} \text { and } 3 \mathrm{M}_{2} \\
\end{array}$ & \multirow[t]{2}{*}{$\begin{array}{c}10 \text { teeth sampled from } 10 \text { individuals } \\
5 \mathrm{M}_{3} \text { and } 5 \mathrm{M}_{2} \\
\text { Microwear } 3 \mathrm{M}_{3} \text { and } 2 \mathrm{M}_{2} \\
\text { Carbon } 1 \mathrm{M}_{3} \text { and } 1 \mathrm{M}_{2} \\
\text { Strontium } 2 \mathrm{M}_{3} \mathrm{~s} \text { and } 5 \mathrm{M}_{2}\end{array}$} & \multirow{2}{*}{$\begin{array}{c}9 \text { teeth sampled from } 7 \text { individuals } \\
7 \mathrm{M}_{3} \text { and } 2 \mathrm{M}_{2} \\
\text { Microwear } 4 \mathrm{M}_{3} \text { and } 2 \mathrm{M}_{2} \\
\text { Carbon } 4 \mathrm{M}_{3} \text { and } 1 \mathrm{M}_{2} \\
\text { Strontium } 6 \mathrm{M}_{3} \text { and } 1 \mathrm{M}_{2} \\
6 \text { microwear, } 5 \text { carbon, } 7 \text { strontium }\end{array}$} \\
\hline & & $\begin{array}{c}\text { BG } \\
2 \text { teeth sampled from } 2 \text { individuals } \\
2 \mathrm{M}_{3} \\
\text { Microwear } 2 \mathrm{M}_{3} \\
\text { Carbon } 1 \mathrm{M}_{3} \\
\text { Strontium } 2 \mathrm{M}_{3} \\
7 \text { microwear, } 5 \text { carbon, } 7 \text { strontium }\end{array}$ & & \\
\hline \multirow{3}{*}{$\begin{array}{l}\text { PPNA } \\
\text { \& LEP }\end{array}$} & & & \multirow{2}{*}{$\begin{array}{c}\text { SH6 } \\
5 \text { teeth sampled from } 4 \text { individuals } \\
3 \mathrm{M}_{3} \text { and } 2 \mathrm{M}_{2} \\
\text { Microwear } 2 \mathrm{M}_{3} \text { and } 2 \mathrm{M}_{2} \text { Carbon } 1 \mathrm{M}_{3} \text { and } \\
1 \mathrm{M}_{2} \\
\text { Strontium } 2 \mathrm{M}_{3} \text { and } 1 \mathrm{M}_{2} \\
\end{array}$} & \\
\hline & & & & \\
\hline & & & $\begin{array}{c}\text { SH } 1 \\
6 \text { teeth sampled from } 5 \text { individuals } \\
3 \mathrm{M}_{3} \text { and } 3 \mathrm{M}_{2} \\
\text { Microwear } 2 \mathrm{M}_{3} \text { and } 3 \mathrm{M}_{2} \\
\text { Carbon } 2 \mathrm{M}_{3} \text { and } 1 \mathrm{M}_{2} \\
\text { Strontium } 2 \mathrm{M}_{3} \text { and } 1 \mathrm{M}_{2} \\
\mathbf{9} \text { microwear, } 5 \text { carbon, } 6 \text { strontium }\end{array}$ & \\
\hline \multirow{3}{*}{$\begin{array}{c}\text { EEP \& } \\
\text { MEP }\end{array}$} & KHIV & $\mathrm{AQ}$ & & \\
\hline & $\begin{array}{c}22 \text { teeth sampled from } 20 \text { individuals } \\
14 \mathrm{M}_{3} \text { and } 8 \mathrm{M}_{2} \\
\text { Microwear } 14 \mathrm{M}_{3} \text { and } 5 \mathrm{M}_{2} \\
\text { Carbon } 7 \mathrm{M}_{3} \text { and } 4 \mathrm{M}_{2} \\
\text { Strontium } 5 \mathrm{M}_{3} \text { and } 7 \mathrm{M}_{2}\end{array}$ & \multirow[t]{2}{*}{$\begin{array}{c}17 \text { teeth sampled from } 16 \text { individuals } \\
14 \mathrm{M}_{3} \text { and } 3 \mathrm{M}_{2} \\
\text { Microwear } 14 \mathrm{M}_{3} \text { and } 3 \mathrm{M}_{2} \\
\text { Carbon } 10 \mathrm{M}_{3} \text { and } 2 \mathrm{M}_{2} \\
\text { Strontium } 8 \mathrm{M}_{3} \text { and } 3 \mathrm{M}_{2}\end{array}$} & & \\
\hline & $\begin{array}{c}\text { WJ6 } \\
3 \text { teeth sampled from } 2 \text { individuals } \\
2 \mathrm{M}_{3} \text { and } 1 \mathrm{M}_{2} \\
\text { Microwear } 2 \mathrm{M}_{3} \text { and } 1 \mathrm{M}_{2} \\
\text { Carbon } 2 \mathrm{M}_{3} \\
\text { Strontium } 2 \mathrm{M}_{3} \\
\mathbf{2 2} \text { microwear, } \mathbf{1 3} \text { carbon, } \mathbf{1 4} \text { strontium }\end{array}$ & & & \\
\hline
\end{tabular}

Table 4. Summary of analyses by site, arranged into cohorts for analysis. Each site shows number of teeth and individual animals and microwear, carbonate and strontium analysed in $\mathrm{M}_{3} \mathrm{~s}$ and $\mathrm{M}_{2} \mathrm{~s}$. The final totals show the number of analyses in each analytical cohort. 


\begin{tabular}{|c|c|c|c|c|}
\hline Isotope & 1st cohort & 2nd cohort & $t$ & $p$ \\
\hline \multirow{3}{*}{$\begin{array}{c}87 / 86 \\
\text { Strontium }\end{array}$} & KHIV \& WJ6 (N=13) & AQ $(\mathrm{N}=12)$ & $6.7165 \dagger$ & $<0.001^{*}$ \\
\hline & KHIV \& WJ6 (N=13) & WJ13 (N=7) & -8.6851 & $<0.001 *$ \\
\hline & $\mathrm{AQ}(\mathrm{N}=12)$ & $\mathrm{AZ31} \& \mathrm{BG}(\mathrm{N}=5)$ & -0.9268 & 0.376 \\
\hline \multirow{3}{*}{$\begin{array}{c}\delta^{18} \\
\text { Oxygen }\end{array}$} & KHIV, WJ6, AQ, SH1 \& SH6 (N=31) & AG, DH, AZ31, BG \& WJ13 (N=23) & 1.0037 & 0.324 \\
\hline & $\mathrm{AQ}(\mathrm{N}=12)$ & AZ31 \& BG $(\mathrm{N}=5)$ & $-2.8653 \dagger$ & $0.017 *$ \\
\hline & KHIV, WJ6, AQ, SH1, SH6, DH, AZ31, BG \& WJ13 (N=44) & $\mathrm{AG}(\mathrm{N}=5)$ & 3.3036 & $0.002^{*}$ \\
\hline \multirow{4}{*}{$\begin{array}{c}\delta^{13} \\
\text { Carbon }\end{array}$} & KHIV, WJ6, AQ, SH1, SH6, DH, AZ31, BG \& WJ13 (N=36) & AG, AZ31, BG \& WJ13 (N=18) & -0.18703 & 0.853 \\
\hline & KHIV \& WJ6 (N=13) & $\mathrm{WJ} 13(\mathrm{~N}=7)$ & -2.1672 & $0.049^{*}$ \\
\hline & $\mathrm{AQ}(\mathrm{N}=12)$ & $\mathrm{AZ} 31 \& \mathrm{BG}(\mathrm{N}=5)$ & -1.0905 & 0.301 \\
\hline & KHIV, WJ6, AQ, SH1, SH6, DH, AZ31, BG, WJ13 (N=44) & $\mathrm{AG}(\mathrm{N}=5)$ & 1.4157 & 0.166 \\
\hline
\end{tabular}

Table 5. Summary of statistical tests performed on cohort isotope results

$*=$ Significant difference at $\mathrm{p}<0.05 . \dagger=$ Welch's $\mathrm{t}$-test for unequal variance. 